\title{
Avrupa Birliği’nde Kredi Kurumlarının Kurulmaları, Faaliyet İzni Almaları ve Faaliyetlerinin Sona Ermesi
}

\author{
Establishment and authorisation of credit institutions and termination \\ of their activities in the European Union
}

\section{Prof. Dr. Gürgân ÇELEBİCAN*}

I. Giriş, II. Avrupa Birliği’nin Kredi Kurumlarına İlişkin Düzenlemeleri, III. Kredi Kurumunun Tanımı, IV. 2006/48/EC sayılı Yönergenin Kapsamı Dışında Bırakılan Kurumlar, V. Kredi Kurumlarının Kuruluşu ve Hukukî Şekli, VI. Faaliyet İzni, VII. Faaliyet İzninin Verilebilmesi İçin Varlığı Aranan Koşullar, VIII. Tek Bankacılık Lisansı, IX. Tek Bankacılık Lisansı ve Malî Kurumlar, X. Faaliyet İzninin Geri Alınması, XI. Hukuk Yollarına Başvurma Hakkı, XII. Kredi Kurumlarının Faaliyetlerinin Sona Ermesi, XIII. Son Söz

\section{ÖZET}

Avrupa Birliği’nin yönergelerinde banka ve bankacıllk sözcükleriyle zaman zaman karşılaşılsa da, daha çok, kredi kurumu deyiminin kullanıldığı gözlemlenmektedir. 2006/48/EC sayılı yönergeye göre kredi kurumu deyimi, kamudan mevduat ya da geri ödenmek üzere başka türden fonlar toplamak ve kendi hesabına kredi vermek olan bir teşebbüsü veya elektronik para kurumunu ifade eder. Bu kurumlar, faaliyete başlayabilmek için kuruldukları Üye Devletteki yetkili mercilerden izin almak zorundadırlar. Faaliyet izni, yetkili mercilerce düzenlenen ve bir kredi kurumunun işlemlerini yapma hakkını veren bir hukukî beyandır. Faaliyet izninin alınabilmesi için

\footnotetext{
* Ankara Üniversitesi Hukuk Fakültesi Emekli Öğretim Üyesi.
} 
Yönerge'de belirlenmiş olan koşulların yerine getirilmesi gerekir. Kredi kurumu bu izne dayanarak Topluluğun her yerinde ve ayrı bir izin almaksızın şube açabilir; sınır ötesi hizmet sunabilir. Tüm Üye Devletlerde geçerli olduğu için bu izne Tek Bankacılık Lisansı denmektedir. Faaliyet izni ancak Yönerge'de belirlenen nedenlerle geri alınabilir. Kredi kurumları iradî ya da zorunlu olarak tasfiye edildiklerinde faaliyetlerini sona erdirmiş olurlar.

Anahtar Kelimeler: Kredi kurumu, Tek Bankacılık Lisans1, Faaliyet İzni, 2006/48/EC sayılı yönerge, Köken Devletin denetimi ilkesi

\begin{abstract}
Although bank and banking are the words one may encounter every now and then in the Directives of the European Union, the term preferred is credit institution, which is described by Directive 2006/48/EC as an undertaking whose business is to receive deposits and other repayable funds from the public and to grant credits for its own account; or an electronic money institution within the meaning of Directive 2000/46/EC. These institutions are required to obtain authorisation from the competent authorities of their home Member State before commencing their activities. Authorisation means any instrument issued in any form by the authorities by which the right to carry on the business of a credit institution is granted. To obtain authorisation credit institutions must fulfill the requirements laid down in Directive 2006/48/EC. The institutions duely authorised in one of the Member States are allowed to pursue the business of credit institutions throughout the Community either by the establishment of branches or by way of the provision of services without prior approval from the authorities of a particular country. Competent authorities may withdraw the authorisation granted to a credit institution only where the institution fails to satisfy the conditions laid down in the Directive. Credit institutions' activities may also be terminated where the opening of winding-up proceedings is decided and when it is eventually wound-up.
\end{abstract}

Keywords: Credit institutions, Single Banking Licence, Authorisation, Directive 2006/48/EC, Home Country Control Principle

I. Giriş: Avrupa Birliği'nin hukuksal düzenlemelerinde banka ya da bankacılık sözcükleriyle zaman zaman karşılaşılsa da kredi kurumu deyiminin genellikle yeğlendiği görülmektedir. Bunun başlıca nedeni, banka deyimine verilen anlamın bir Üye Devletten ötekine fark göstermesidir. ${ }^{1}$ Üye

1 Paola CLAROTTI: The Harmonisation of Legislation Relating to Credit Institutions, Common Market Law Review, vol:19 No:2 1982, sh.245; keza bk.Georgios ZAVVOS: Towards a European Banking Law, Common Market Law Review, No:25 1988, sh.272273. 
Devletlerin bazılarında yalnız belirli işlemleri yapma yetkisine sahip olan kuruluşlara banka adı verilmiş, bazılarında ise bu deyimi tanımlama yoluna gidilmemiştir. Bazı Üye Devletlerde bankalarınkine benzer işlemler yapmakla birlikte banka olmayan kurumlar, bazı Üye Devletlerde bankacılık işlemleri yapan fakat banka adını taşımayan kurumlar faaliyet göstermektedir. Oysa, kredi kurumlarına ilişkin ilk önemli düzenleme olan 77/780/EEC sayılı Birinci Bankacılık Yönergesi'nin önsözünde belirtildiği gibi, tasarrufları koruyabilmek ve rekabet eşitliğini sağlayabilmek için, taşıdıkları ünvan ne olursa olsun, aynı işlemleri yapan kurumların tümünü aynı düzenlemenin kapsamı içine almak gerekir. Bu amaca yönelik olarak, Avrupa Birliği'nin malî kesime ilişkin düzenlemelerinde kredi kurumu gibi olabildiğince geniş kapsamlı bir deyimin kullanılması yoluna gidilmiştir.

II. Avrupa Birliği'nin Kredi Kurumlarına İlişkin Düzenlemeleri: "Bankaların ve Öteki Malî Kurumların Bağımsız Faaliyetleri Bakımından Yerleşme Serbestisi ve Hizmet Sunma Serbestisi Üzerindeki Kısıtlamaların Kaldırılmasına İlişkin 28 Haziran 1973 günlü ve ve 73/183/EEC sayılı Konsey Yönergesi”’ bir yana bırakılırsa, yukarda değinildiği gibi, kredi kurumlarına ilişkin ilk önemli düzenleme, "Kredi Kurumlarının Kurulmalarına ve Faaliyetlerine İlişkin Kanun, Tüzük ve İdarî Düzenlemelerin Eşgüdümü Hakkında 12 Aralık 1977 günlü ve 77/780/EEC sayılı Birinci Bankacılık Yönergesi”dir. ${ }^{3}$ İzleyen yıllarda kredi kurumlarının gözetim ve denetimine, düzenleyecekleri ylllı hesaplara ve konsolide hesaplara, yıllık muhasebe belgelerinin yayınlanmasına, açacakları tüketici kredilerine ve sahip olmaları gereken özkaynaklara ilişkin kurallar koyan çeşitli yönergelerin, ard arda, çıkarılıp yürürlüğe konmasından sonra gerçekleşen bir başka önemli gelişme, Topluluğun ilk Bankalar Yasası sayılabilecek olan, "Kredi Kurumlarının Kurulmalarına ve Faaliyetlerine İlişkin Kanun, Tüzük ve İdarî Düzenlemelerin Eşgüdümü Hakkında ve 77/780/EEC sayılı Yönergeyi Değiştiren 15 Aralık 1989 günlü ve 89/646/EEC sayılı İkinci Konsey Yönergesi”nin ${ }^{4}$ kabul edilmesidir. Bu gelişmenin ardından gelen dönemde, kredi kurumlarının borç ödeme gücünün ölçülmesine ve korunmasına, şubelerce kamuya açıklanması gereken belge ve bilgilere, kredi kurumlarının büyük risklerinin izlenmesine ve denetlenmesine, sermaye yeterliliğine, mevduatı garanti etmek üzere kuracakları ya da katılacakları sistemlere, yeniden yapılandırılmalarına ve

${ }^{2}$ Council Directive 73/183/EEC of 28 June 1973 on the abolition of restrictions on freedom of establishment and of freedom to provide services in respect of self-employment activities of banks and other financial institutions, OJ L 194 16.07.1973, sh.1-10.

${ }^{3}$ First Council Directive 77/780/EEC of 12 December 1977 on the coordination of laws, regulations and administrative provisions relating to the taking up and pursuit of the business of credit institutions, OJ L 322 17.12.1977, sh.30-37.

${ }^{4}$ Second Council Directive 89/646/EEC of 15 December 1989 on the coordination of laws, regulations and administrative provisions relating to the taking up and pursuit of the business of credit institutions and amending Directive 77/780/EEC, OJ L 386 30.12.1989, sh.1-13. 
tasfiyelerine ilişkin çeşitli yönergeler çıkarılmıştır. $\mathrm{Bu}$ düzenlemelerin hemen hemen tümü, ortaya çıkan gereksinmeleri karşılamak üzere, çıkarılan başka yönergelerle zaman zaman, küçük ya da büyük ölçüde, değiştirilmiştir. Kredi kurumlarına ilişkin düzenlemelerde ortaya çıkan dağınıklığı gidermek, düzenlemelere açılık ve rasyonellik sağlamak için, birbirleriyle yakın bağıntıları olan yönergeleri tek bir metinde birleştirme yoluna gidilmiş ve bu amaçla “Avrupa Parlâmentosu'nun ve Konsey'in Kredi Kurumlarının Kurulmalarına ve Faaliyette Bulunmalarına İlişkin 2000/12/EC sayılı ve 20 Mart 2000 günlü Yönergesi”" çıkarılmıştır. Yönerge, 67. maddesinde saydığı bir dizi yönergeyi ${ }^{6}$ yürürlükten kaldırmış, fakat bunların hükümlerini tek bir metin halinde içselleştirmiştir. Ne var ki, bu yönerge de bir kaç kez ve önemli ölçüde değişikliklere uğradığından yürürlükten kaldırılarak hükümleri “Avrupa Parlâmentosu'nun ve Konsey'in Kredi Kurumlarının Kurulmalarına ve Faaliyette Bulunmalarına İlişkin 2006/48/EC sayılı ve 14 Haziran 2006 günlü Yönergesi”ne ${ }^{7}$ aktarılmıştır. 2000/12/EC sayılı düzenlemeyle birlikte, doğal olarak, bu düzenlemede değişiklikler yapmış olan yönergeler ${ }^{8}$ de 158 . madde gereğince yürürlükten kaldırılmış, fakat içerdikleri hükümler yeni yönergenin metni içine alınmıştır; maddenin 2 . endine göre, kaldırılan yönergelere yapılmış olan göndermeler 2006/48/EC sayılı yönergeye yapılmış sayılacaktır. Benzer bir uygulama, "Avrupa Parlâmentosu'nun ve Konsey'in Malî Yatırım Firmaları ile Kredi Kurumlarının Sermaye Yeterliliğine İlişkin 2006/49/EC sayılı ve 14 Haziran 2006 günlü Yönergesi"” ile gerçekleştirilmiştir. Sözü edilen yönerge 52. maddesinde, "Malî Yatırım Firmaları ile Kredi Kurumlarının Sermaye Yeterliliğine İlişkin 93/6/EEC sayılı ve 15 Mart 1993 günlü Konsey Yönergesi"nin ${ }^{10}$ ve değişikliklerinin yürürlükten kaldırıldığı; fakat Üye Devletlerin bu düzenlemeler nedeniyle üstlendikleri yükümlülüklerinin sürdüğü hükmü yer almaktadır. Kredi kurumlarına ilişsin en kapsamlı düzenleme, bugün için, 2006/48/EC say1lı yönergedir.

${ }^{5}$ Directive 2000/12/EC of the European Parliament and of the Council of 20 March 2000 relating to the taking up and pursuit of the business of credit institutions, OJ L 126 26.05.2000, sh.1-59.

${ }^{6}$ 73/183/EEC, 77/780/EEC, 89/299/EEC, 89/646/EEC, 89/647/EEC, 92/30/EEC, 92/121/EEC sayılı yönergeler ile bunlarda değişiklik yapmış olan yönergeler.

${ }^{7}$ Directive 2006/48/EC of the European Parliament and of the Council of 14 June 2006 relating to the taking up and pursuit of the business of credit institutions (recast), OJ L 177 30.06.2006, sh.1-200.

8 2000/12/EC, 2000/28/EC, 2000/8/EC (29. maddesinin bazı bendleri), 2004/39/EC (yalnız 68. maddesi), 2004/69/EC, 2005/1/EC (yalnız 3. maddesi) sayılı yönergeler.

${ }^{9}$ Directive 2006/49/EC of the European Parliament and of the Council of 14 June 2006 on the capital adequacy of investment firms and credit institutions (recast), OJ L 177 30.06.2006, sh.201-248.

${ }^{10}$ Council Directive 93/6/EEC of 15 March 1993 on the capital adequacy of investment firms and credit institutions, OJ L 141 11.06.1993, sh.1-26. 
III. Kredi Kurumunun Tanımı: Kredi kurumu deyimi, yürürlükten kaldırılarak hükümleri önce 2000/12/EC say1lı, daha sonra 2006/48/EC sayılı yönergeye aktarılan 77/780/EEC sayılı Birinci Bankacılık Yönergesi'nin 1. maddesinde tanımlanmıştır. Maddede tanımın salt 77/780/EEC sayılı yönergedeki düzenleme ile ilişkili olduğu belirtilmişse de, 2000/28/EC sayılı yönerge ile değişiklik getirilinceye kadar, çıkarılan yönergelerde deyim yeniden tanımlanmamış, Birinci Bankacılık Yönergesi'ne gönderme yapmakla yetinilmiştir. ${ }^{11} \mathrm{Bu}$ maddeye göre "kredi kurumu, faaliyet konusu kamudan mevduat ya da geri ödenmek üzere başka türden fonlar toplamak ve kendi hesabına kredi vermek olan teşebbüsü ifade eder."

Geleneksel malî aracılık anlayışına dayanan bu tanıma göre kredi kurumunun ayırıcı özellikleri,

1. kamudan, başka bir deyişle, yurtiçindeki ya da yurtdışındaki gerçek kişilerden, firmalardan, özel ve kamusal tüzel kişilerden, kurum ve kuruluşlar ile benzerlerinden mevduat olarak veya tahvil, varlığa dayalı menkul kıymet, yatırım fonu gibi malî araçlar çıkararak fonlar toplaması;

2. kabul ettiği fonları, önceden belirlenen koşullara göre geri vermeyi üstlenmesi;

3. kendi hesabına kredi vermesi ve

4. kamunun yatıracağı fonları kabul etmesinin yanı sıra, kendi hesabına kredi vermesi; bir başka deyişle, fon toplamaya ve kredi vermeye aynı zamanda yetkili olmasıdır.

Faaliyet konusu salt kamudan mevduat ve geri ödenebilir fonlar toplamak ya da yalnız kredi vermek olan bir teşebbüs, Yönerge'deki anlamda kredi kurumu sayılmaz. Bu nedenle, İngiltere'deki bazı kuruluşlar gibi mevduat kabul eden fakat kredi vermeyen teşebbüsler, banka ünvanı taşısalar da, Yönerge' deki tanımın kapsamına girmezler. ${ }^{12}$ Aynı şekilde, salt

${ }^{11}$ İkinci Bankacılık Yönergesi’nin öneri metninde kredi kurumunun tanımı, mevduat ve geri ödenmek üzere başka türden fonlar toplayan ya da kredi açan teşebbüsleri de kapsayacak biçimde genişletilmişti. Bu yolla, malî piyasalarda uzmanlaşmanın zayıflaması ve serbestleşme sonucu ortaya çıkan ve salt fon toplayarak ya da yalnız kredi vererek bankalarla rekabet eden yeni tür teşebbüslerin de yetkili mercilerin gözetim ve denetimi altına alınması amaçlanmıştı. Ayrıca, tanımın genişletilmesi suretiyle, ilerdeki VIII. kesimde ele alınacak olan Tek Bankacılık Lisansı'nın karşı1ıklı tanıma olanağını daha geniş bir işlemler yelpazesine sağlayabileceği düşünülmüştü. Ancak, bazı Üye Devletlerin karşı çıkması üzerine kredi kurumunun tanımı değiştirilmedi ve kredi kurumlarının karşılıklı tanıma ilkesinden yararlanabilecekleri işlemlerin sayısının arttırılmasıyla yetinildi. Bk. G.S.ZAVVOS: Banking Integration and 1992: Legal Issues and Policy Implications, Harvard International Law Journal, vol:31 No:2 Spring 1990, sh.478.

12 Yürürlükten kaldırılmış olan İkinci Bankacıllk Yönergesi’nin 3. maddesi ve bugün yürürlükte bulunan 2006/48/EC sayılı yönergenin 5. maddesi Üye Devletleri, şahısların ve kredi kurumu olmayan teşebbüslerin kamudan mevduat ve geri ödenebilir fonlar kabul etmesini yasaklamakla yükümlü kılmıştır. 
para piyasasından ya da bankalar sisteminden sağladıkları fonları veya sadece kendi malî kaynaklarını kullanarak kredi açan kuruluşlar da Yönerge'nin kabul ettiği anlamda kredi kurumu değildirler. Öte yandan, bir teşebbüsün kredi kurumu sayılabilmesi için kamudan topladığı fonları geri ödenmek üzere kabul etmiş olması gerekir. Bu nedenle, kamudan fon toplamalarına karşın sosyal sigorta kurumları, sigorta ortaklıkları ya da kollektif yatırım kurumları kredi kurumu sayılmazlar. Aslî faaliyet konuları olmadığ müşterilerine kredi kolaylıkları sağlayan ticarî teșebbüsler ve bankacılık kesimindeki aracılar da tanımın kapsamı dışındadır. ${ }^{13}$

Bir teşebbüsün kredi kurumu sayılabilmesi için statüsüyle ya da ilgili mercilerden aldığı faaliyet izniyle hem mevduat kabul etmeğe ve çeşitli yollardan giderek fonlar toplamağa hem de kendi hesabına kredi vermeğe yetkili kılınmış olması yeterlidir. Mevduat kabulü ve fon toplama ile kredi verme işlemlerinin aynı zaman dilimi içinde yapılması zorunlu olmadığı gibi, teşebbüsün yetkili kılındığı iki tür işlemden birini sürekli değil aralıklı olarak yapması veya hiç yapmaması da mümkündür; örneğin ana sözleşmesi yahut kendisine verilen faaliyet izni ile kamudan mevduat ve fon toplamaya, ayrıca kredi vermeğe yetkili kılınmış bir konsorsiyum bankasının kamudan toplayacağı mevduat ve fonlar yerine, kendine özgü ticarî nedenlerle, ana kuruluşlardan ya da bankalararası para piyasasından sağladığı kaynakları kullanarak kredi verme yoluna gitmesi, kredi kurumu sayılmasını engellemez. ${ }^{14}$

Kredi kurumunun tanımında yer alan mevduat ve geri ödenmek üzere toplanan başka türden fonlar deyimleri, uzun boylu tartışmay1 gerektirmeyecek ölçüde açık anlamlara sahiptir. Buna karşıllı, kredi kurumunun kendi hesabina vereceği kredinin belirlenmesi gerekmektedir. Gerçekten, aynı işlem bazı Üye Devletlerde kredi açma olarak nitelendirilmekte, öteki bazı Üye Devletlerde ise kredi işlemi sayılmamaktadır; örneğin, finansal kiralama (leasing), Fransa ve Belçika'da kredi işlemi olarak kabul edilmekte, dolayısıyla bu ülkelerde kamudan her hangi bir şekilde fon toplayan finansal kiralama teşebbüslerini de kredi kurumu olarak nitelemek gerekmektedir. Almanya'da ise finansal kiralama işlemi bir kredi türü olarak kabul edilmediği için bu alanda uzmanlaşmış olan teşebbüsleri, bir şekilde fon toplasalar da, kredi kurumu saymak söz konusu olamamaktadır. Birinci Bankacılık Yönergesi'nde kredi işlemlerinin ortak bir tanımı yapılmamış olduğundan, hangi bankacılık işleminin kredi sayılacağını Üye Devletlerin ulusal düzenlemelerine göre belirlemekten başka yol kalmiyordu. Ne var ki, bu yola gidildiğinde Topluluk ölçeğinde ve tekdüze bir uygulamanın gerçekleşmesi elbette söz konusu olamaz. Bununla

\footnotetext{
${ }^{13}$ Marc DASSESSE - Stuart ISAACS - Graham PENN: EC Banking Law, London 1994, 2nd ed. sh.19.

${ }^{14}$ P.CLAROTTI: a.g.m. sh.249.
} 
birlikte, önce İkinci Bankacılık Yönergesi'nin, daha sonra 2000/12/EC sayılı yönergenin ve en sonunda bunların yerini alan 2006/48/EC sayılı yönergenin Karşılıklı Tanımaya Tâbi Faaliyetler Listesi başlığını taşıyan eklerinde, borç verme örnekleri olarak tüketici kredilerinin, ipotek karşıllı̆ı kredilerin, rüculu ve rücusuz faktoringin, forfeytingi de içermek üzere ticarî ișlemlerin finansmanının sayılması tekdüzeliğin sağlanmasına bir ölçüde katkı yapabilir. Ancak, sözü edilen listenin bir başka amaçla düzenlendiği gözden uzak tutulmamalidır.

Birinci Bankacılık Yönergesi'nin getirdiği ve son olarak 2000/12/EC sayılı yönergenin de benimsediği kredi kurumu tanımında 2000/28/EC sayılı yönerge $^{15}$ ile bir değişiklik yapılmış ve nitelikleri 2000/46/EC sayılı yönergede $^{16}$ gösterilen elektronik para kurumları tanım kapsamına alınmıştır. Yönerge'de elektronik para, elektronik bir cihaza yüklenmiş bulunan; miktarı ihraç edilen parasal değerden daha az olmayan fonların kabul edilmesi karşılığında çıkarılan; ihraç eden kurumun dışındaki öteki teşebbüslerce de ödeme aracı sayılan ve ihraç eden kurumdan bir alacağı temsil eden parasal değer olarak tanımlanmıştır. Bir başka ifade ile elektronik para, madenî ve kâğıt paraların yerini tutan, genellikle elektronik ortamda ve miktarı sınırlı ödemeler yapmakta kullanılmak üzere yonga kartı ya da bilgisayar belleği gibi bir cihazda saklanan elektronik kayıtlardır. Yönerge' ye göre elektronik para kurumu deyimi ise, elektronik para şeklinde ödeme aracı ihraç eden bir teşebbüsü ya da her hangi bir tüzel kişiyi ifade eder.

Yapılan değişikliği de içeren ve bugün yürürlükteki düzenleme olan 2006/48/EC say1lı yönergenin 4. maddesinin 1. bendine göre kredi kurumu, “a) faaliyet konusu kamudan mevduat ya da geri ödenmek üzere başka türden fonlar toplamak ve kendi hesabına kredi vermek olan teşebbüsü veya b) 2000/46/EC sayılı yönergedeki anlamıla elektronik para kurumunu" ifade eder.

IV. 2006/48/EC sayılı Yönergenin Kapsamı Dışında Bırakılan Kurumlar: Birinci Bankacılık Yönergesi ile başlatılan uygulamayı sürdüren 2006/48/EC say1lı yönerge, 4. maddesindeki tanıma uygun nitelikte olsalar da, 2. maddesinde saydığı kurumları kapsam dışı bırakmıştır. Söz konusu maddeye göre Yönerge, Üye Devletlerin Merkez Bankaları ile posta (PTT) ciro kurumlarına uygulanmayacaktır. Ayrıca, Üye Devletlerde faaliyet gösteren ve maddenin adlarını belirtilerek saydığı kurumlar da kapsam dışı bırakılmıştır. Bu sonuncu kurumlar belirlenirken hangi ölçütün kullanıldığı

${ }^{15}$ Directive 2000/28/EC of the European Parliament and of the Council of 18 September 2000 amending Directive 2000/12/EC relating to the taking up and pursuit of the business of credit institutions, OJ L 275 27.10.2000, sh.37-38.

${ }^{16}$ Directive 2000/46/EC of the European Parliament and of the Council of 18 September 2000 on the taking up, pursuit of and prudential supervision of the business of electronic money institutions, OJ L 275 27.10.2000, sh.39-43. 
belli değildir. Yönerge'nin önsözünde, belirli bazı kredi kurumları için istisnalar getirilmesi gereğinden söz edilmekle yetinilmiştir. Aslında, maddede sayılan bazı kurumların Yönerge'deki tanıma ne ölçüde uydukları da tartışmaya açıktır. Belki, bu kurumlardan bazılarının özel kredi kurumları ile doğrudan rekabete girmeyen ve daha çok kamusal hizmete benzer faaliyetler yapan, uzmanlaşmış kurumlar oldukları söylenebilir. Adları maddede sayılmış olan kurumların yapısal bir değişim geçirmelerine gereksinme duyulduğu için kapsam dişında tutuldukları da ileri sürülmüştür. ${ }^{17} 2$. maddede adları belirtilerek sayılan kurumların yer aldığı liste kesin olmayıp gerektikçe değiştirilmektedir. Nitekim, ilk şekliyle Birinci Bankacılık Yönergesi'nin 2. maddesinde yer almış olan liste 27.10.1986 günlü ve 86/524/EEC sayll yönerge ${ }^{18}$ ile değiştirilmiştir. 2006/48/EC sayılı yönerge'nin 150 . maddesinin $1 /$ d bendi ile 2 . maddede teknik uyarlamalar yapma yetkisi verilmiş olan Komisyon bu listeyi gerektikçe değiştirebilmektedir. ${ }^{19}$ Öte yandan, Avrupa Birliği yeni katılımlarla genişledikçe, doğal olarak, listeye eklemeler yapılmaktadır.

V. Kredi Kurumlarının Kuruluşu ve Hukukî Şekli: Kredi kurumlarının kurulmalarına ve faaliyette bulunmalarına ilişkin 2006/48/EC sayılı yönergenin 6. maddesinde, "Üye Devletler, kredi kurumlarının faaliyete geçmeden önce faaliyet izni almalarını zorunlu kılarlar." denmiş olmasına bakarak, Avrupa Birliği'nde kredi kurumlarının kurulması ile işlemlere başlamak için izin almalarının birbirini izleyen iki ayrı aşama olarak öngörüldüğü sonucuna varılabilir. Başka bir deyişle önce, kamudan mevduat ya da geri ödenmek üzere fonlar toplama ve kendi hesabına kredi verme işlemleri yapacak bir teşebbüs kurulacak, daha sonra faaliyet izni alabilmek için yetkili mercilere başvurulacaktır. Ancak, çıkarılmış olan yönergelerde teşebbüsün hangi hukukî şekilde kurulacağına ilişkin açıklık yer almamaktadır. ${ }^{20} \mathrm{Bu}$ boşluğu yorumlayarak, konunun Üye Devletlerin ulusal

\footnotetext{
${ }^{17}$ P.CLAROTTI: a.g.m.sh.259.

${ }^{18}$ Council Directive 86/524/EEC of 27 December 1986 amending Directive 77/780/EEC in respect of the list of permanent exclusions of certain credit institutions, OJ L 309 04.11.1986, sh.15-16.

${ }^{19}$ Commission Directive 2007/18/EC of 27 March 2007 amending Directive 2006/48/EC of the European Parliament and of the Council as regards the exclusion or inclusion of certain institutions from its scope of application and the treatment of exposures to multilateral development banks, OJ L 8728.03 2007, sh.9-10.

${ }^{20}$ Tarihsel olarak bankacılık piyasaları Avrupa ölçeğinde değil fakat her ülkede birbirinden bağımsız olarak gelişme göstermiştir. Ayrıntılar bir yana bırakılırsa Avrupa'daki kredi kurumları, ticaret bankaları, tasarruf bankaları, kooperatif bankalar, ipotek karşılığı kredi veren mortgage bankaları ve building societies olmak üzere dört başlık altında toplanabilir. Bu kurumların hukukî şekilleri, anonim ortaklıkdan, limited ortaklığa, karşılıklı tasarruf sandıklarından özel ve kamusal vakıflara kadar değișen bir yelpazenin içinde yer almaktadır. Bunlara ek olmak üzere, Avrupa Topluluğu hukukuna dayanılarak, kısaca Societas Europeae (SE) ve Societas Cooperativa Europeae (SCE) olarak adlandırılan iki yeni ortaklık statüsü yaratılmıştır. Bk.World Savings Banks Institute (WSBI) \& European
} 
düzenlemelerine bırakılmış olduğu, ileri sürülebilir. Nitekim, varlığı artık ayrı bir düzenleme olarak son bulmuş olsa da, Birinci Bankacılık Yönergesi'nin 4. maddesinin 2. bendi, merkezi bir başka Üye Devlette bulunan kredi kurumunca herhangi bir Üye Devlette şube açmak için yapılan başvurunun, salt o ülkede izin verilmeyen bir hukukî şekilde kurulmuş olduğu gerekçesiyle geri çevrilmesini yasaklamıştı. Öte yandan, Roma Antlaşması'nın 58. maddesinin 1. fıkrasında, yerleşme hakkı ile ilintili olarak, "Üye Devletlerin hukukuna göre kurulmuş olan ortaklıklar ya da firmalar"dan söz edilmektedir. Aynı maddenin 2. fıkrasına göre de, "Ortaklıklar ya da firmalar, kooperatif ortaklıkları ve kamu hukukuna ya da özel hukuka tâbi öteki tüzel kişileri içermek, fakat kâr amacı gütmeyen kuruluşları dışarda bırakmak üzere, medenî hukuk ya da ticaret hukuku hükümleri uyarınca kurulmuş olan ortaklıkları ya da firmaları ifade eder." Birinci Bankacılık Yönergesi'nden bu yana yönergelerin kabul ede geldikleri tanımda teşebbüs olarak nitelenen kredi kurumlarının, yerleşme hakkından yararlandıkları için, 58. maddede belirtilen anlamda bir ortaklık ya da firma olarak kurulmaları gerektiği ileri sürülebilir. $\mathrm{Bu}$ yorum kabul edilmezse kredi kurumlarını, yerleşme hakkından yararlananlar ve yaralanamayanlar olarak ikiye ayırmak gibi Tekpazar'ın mantığına ve uygulamasına ters düşen bir sonuca ulaşılmış olur. Bu nedenle, kredi kurumu tanımındaki teşebbüs deyimini 58. madde anlamında "ortaklık ya da firma" olarak anlamak doğru olur. Nitekim, 2006/48/EC sayllı yönergenin 9. maddesinin 1. bendinde kredi kurumunun faaliyet izni alabilmesi için ayrı özkaynaklara sahip olmasının zorunlu kılınması, 5. maddesinde de şahısların mevduat ve geri ödenmek üzere fon toplamalarının Üye Devletlerce yasaklanacağının belirtilmesi, bu kurumların tek kişilik bir firma şeklinde kurulamayacağının kanıtı sayılabilir.

Kredi kurumlarının kuruluşlarına ve hukukî şekillerine ilişkin olarak denilebilir ki,

1. Avrupa Birliği'nin düzenlemelerinde kredi kurumlarının bir ortaklık ya da firma şeklinde kurulmaları ile faaliyet izni alarak mevduat ve fon toplama, kendi hesabına kredi verme işlemlerine başlamaları iki ayrı ve birbirini izleyen aşamalar olarak öngörülmüştür;

Savings Bank Group (ESBG): A Comparative Analysis of the US and EU Retail Banking Markets, a contribution in the context of the EU/US retail banking forum, September 2006, sh.32 vd. Ayrica bk. Council Regulation (EC) No:2157/2001 of 8 October 2001 on the Statute for a European company, OJ L 294 10.11.2001, sh.1-21 ve Council Directive 2001/86/EC of 8 October 2001 supplementing the Statute for a European company with regard to the involvement of employees, OJ L 294 10.11.2001, sh.22-32; keza bk. Council Regulation (EC) No:1435/2003 of 22 July 2003 on the Statute for a European Cooperative Society (SCE), OJ L 207 18.08.2003, sh.1-24 ve Council Directive 2003/72/EC of 22 July 2003 supplementing the Statute for a European Cooperative Society with regard to the involvement of employees, OJ L 207 18.08.2003, sh.25-36. 
2. kredi kurumları, Roma Antlaşması'nın 58. maddesinde çizilen sınırlar içinde kalma koşuluyla, Üye Devletlerin ulusal düzenlemelerinde yer alan her hangi bir hukukî şekilde kurulabilirler;

3. kredi kurumları, vakıf gibi kâr amacı gütmeyen bir kuruluş olarak kurulamazlar.

Avrupa Birliği’nin düzenlemelerinde kredi kurumlarının bir teşebbüs olarak kuruluşlarına ve hukukî şekillerine ilişkin ayrıntılı hükümlerin bulunmamasına karşın, bu kurumların bankacılık işlemlerine başlayabilmek için almaları zorunlu olan faaliyet izninin verilmesi sıkı koşullara bağlanmıştır. Avrupa Birliği'nde kredi kurumlarının faaliyet izni alabilmek için sahip olmaları gereken niteliklere ve yerine getirmeleri zorunlu tutulan koşullara, nasıl ve hangi hukukî şekillerde kuruldukları sorularının yanıtlarından daha fazla önem verildiği gözlemlenmektedir.

VI. Faaliyet İni: 2006/48/EC say1lı yönergenin 6. maddesine göre Üye Devletler, merkezleri kendi ülkelerinde bulunan ve kredi kurumlarına özgü işlemler yapmak üzere kurulan teşebbüslerin faaliyete başlamadan önce yetkili mercilere başvurarak izin almalarını sağlamakla yükümlüdürler. Kredi kurumları, bir başka Üye Devlette şube açmayı ya da sınır ötesi hizmet sunmayı amaçlamasalar da Yönerge'de belirlenen koşulları yerine getirerek faaliyet iznini almak zorundadırlar. Bu yükümlülüğü ilk kez getiren Birinci Bankacılık Yönergesi'nin öneri olarak Konsey'e sunulduğu tarihte (1974) bazı Üye Devletlerde (örneğin İngitere'de) faaliyet izni alma zorunluluğunun bulunmayışı, bazılarında ise (örneğin Hollanda) belirli kredi kurumları için söz konusu olmaması, gereksiz gibi görünen böyle bir hükmün kabul edilmesine yol açmıştır.

Faaliyet izni, Yönerge'nin 4. maddesinin 2. bendine göre, yetkili mercilerce her hangi bir şekilde düzenlenen ve bir kredi kurumunun işlemlerini yapma hakkını veren bir hukukî beyandır. Tanımdaki kredi kurumunun işlemleri cümleciğini, sonradan ayrıntılandırılsa da, başlangıçta dar anlamda ve mevduat ya da fon toplama ve kredi açma olarak yorumlamak doğru olur. Yetkili merciler (competent authorities), her Üye Devletin iç hukukuna göre kredi kurumları üzerinde gözetim ve denetim sorumluğuna sahip olan ulusal organlardır. $\mathrm{Bu}$ mercilere baş vuran ve Yönerge' deki koşulları yerine getirmiş olan teşebbüse mevduat ya da fon toplayabileceğine, kredi açabileceğine ilişkin bir yazı yazılması veya bir belge verilmesi, teşebbüsün konuyla ilgili bir resmî sicile kaydedilmesi ${ }^{21}$ faaliyet izninin verilmiş sayılması için yeterlidir. Bununla birlikte, Yönerge'nin 23. maddesine göre kredi kurumları, faaliyet izninde belirtilmiş olma koşuluyla Yönerge'nin 1 Numaralı Ek'inde gösterilmiş bulunan işlemleri şube açtıkları ya da sınır ötesi hizmet sundukları Üye Devletlerde, o ülkelerde kurulmuş kredi kurumlarının yapmalarına izin verilmemiş olsa

${ }^{21}$ M.DASSESSE ve diğ.: a.g.e.sh.20. 
da yapabileceklerinden, sözü edilen maddeden yararlanılabilmesi için Ek 1 'deki işlemlerin tümünün ya da uygun görülenlerin faaliyet izninde açıkca yer alması gerekir. Kuruldukları Üye Devlette, 2006/48/EC sayılı yönergede öngörülen koşulları eksiksiz yerine getirerek ulusal yetkili mercilerden faaliyet izni alan kredi kurumları, başkaca bir izne gerek olmaksızın, tüm öteki Üye Devletlerde şube açabilirler; sınır ötesi hizmet sunabilirler. Topluluğun her yerinde geçerli olan bu faaliyet iznine Tek Bankacılık Lisansi (Single Banking Licence) denmektedir. Kredi kurumlarına verilen faaliyet izinleri, yönergelerde belirtilmiş bulunan ve bunlara ek olarak ulusal düzenlemelerde yer verilen nedenler ortaya çıkmadıkça geri alınamaz.

VII. Faaliyet İzninin Verilebilmesi İçin Varlı̆̆ı Aranan Koşullar: Kredi kurumlarına faaliyet izni verilebilmesi için yerine getirilmesi gereken koşullar, 2006/48/EC sayılı yönergenin 6. ve sonraki maddelerinde ayrıntılı biçimde düzenlenmiştir. Merkezinin bulunduğu Üye Devletin hukukuna uyularak kurulan bir teşebbüsün, kredi kurumu olarak faaliyet göstermek üzere izin alabilmesi için sözü edilen maddelerde belirtilen koşulları yerine getirmesi gereklidir.

1. Faaliyet izni almak için yetkili mercilere baş vuran kredi kurumu, bağımsız özkaynaklara sahip olmalıdır; bir başka deyişle kredi kurumunun, ortağ olmalıdır. Özkaynaklar, kârları aşan boyuttaki zararların karşılanmasında kullanılarak kredi kurumunun sürekliliğini sağlar ve topladığı tasarrufların güvencesini oluşturur; ayrıca, kredi kurumunun borç ödeme gücünün ölçülmesinde yararlanılan önemli bir göstergedir. Özkaynakların tanımı, kapsamı ve içeriği Yönerge'nin 2. bölümündeki düzenlemeyle belirlenmiştir.

2. Faaliyet izninin verilebilmesi için kredi kurumunun başlangıç sermayesinin (initial capital) 5 milyon EUR'dan az olmamas1 gerekir. Başlangıç sermayesi, 9. maddenin 1. bendine göre, Yönerge'nin 57. maddesinin (a) ve (b) bendlerinde belirlenmiş olan sermaye ile yedek akçeleri içerir. Buna göre kredi kurumunun başlangıç sermayesi,

a) 86/635/EEC sayılı yönergenin ${ }^{22} 22$. maddesinde tanımlanan sermayenin $^{23}$ ödenmiş olan bölümüyle, kâr payı birikimli pay senetleri (cumulative preferential shares) hariç, emisyon primlerinin (share premium accounts) toplamının ve

22 Council Directive 86/635/EEC of 8 December 1986 on the annual accounts and consolidated accounts of banks and other financial institutions, OJ L 372 31.12.1986, sh.117.

23 “Taahhüt Edilmiş Sermaye" başlığını taşıyan 22. maddeye göre, "Bu kalem, fiilen taşıdığı ada bakılmaksızın, ulusal hukukça ilgili kurumun hukukî niteliğine uygun olarak, pay sahiplerinin ya da diğer mâliklerin taahhüt ettiği özsermaye (equity capital) sayılan tüm tutarları içerir." 
b) $86 / 635 /$ EEC sayılı yönergenin 23. maddesinde tanımlanmış olan yedek akçeler ${ }^{24}$ ile kesin kâr ve zarar hesabından nakledilen kâr ve zararın toplamının,

birlikte oluşturdukları bir büyüklüktür.

Başlangıç sermayesinin yedek akçelerle kâr ya da zararı kapsayacak biçimde tanımlanmış olması, emisyon primlerinden ve kapsam dışı bırakılmakla birlikte kâr payı birikimli pay senetlerinden söz edilmesi, kredi kurumlarının kurulmaları ile faaliyet izni almalarının iki ayrı aşama olarak gerçekleştirileceğinin bir başka kanıtıdır. Başlangıç sermayesi, kredi kurumunun sahip olması gereken özkaynakların alt sınırını oluşturur. Hiç kuşkusuz, kredi kurumunun pasifleri ve /veya riskleri arttıkça özkaynakların da yeterince arttırılarak başlangıç sermayesinin üzerindeki bir tutara yükseltilmesi gerekir.

Kredi kurumlarının başlangıç sermayesinin en az 5 milyon EUR olması genel kural ise de Üye Devletlerin, malî sistemlerine esneklik kazandırabilmek için, kredi kurumlarının başlangıç sermayesi daha az olan bazı kategorilerine faaliyet izni verilebilmesine Yönerge olanak sağlamıştır. Yönerge'nin 9. maddesinin 2. bendinde belirtilen bu olanağın kullanılabilmesi için,

a) kurumların başlangıç sermayeleri 1 milyon EUR' dan az olmamalıdır;

b) ilgili Üye Devletlerin bu seçeneği kullanmalarının gerekçesi Komisyon'a bildirilmeli ve

c) başlangıç sermayeleri 5 milyon EUR'un altında olan bu kurumların adlarının yer aldığı bir liste Komisyonca Avrupa Birliği'nin Resmî Gazetesi'nde (OJ) yayınlanmalıdır.

3. Faaliyet izninin verilebilmesi için kredi kurumunun işleri en az iki kişi tarafından fiilen yönetilmelidir. Yönetim yetkisinin tek bir kişinin elinde toplanmasının, gerek kredi kurumunun sağlıklı yönetimi gerekse alacaklıların hakları ile tasarrufların korunması açısından sakıncalı olabileceği düşünüldüğü için dört göz ilkesi denilen bu kurala yer verilmiştir. Hiç kuşkusuz, ilkeden beklenen olumlu sonucun doğabilmesi, her iki yöneticinin aynı düzeyde olmasına ve eşit yetkilerle donatılmalarına bağlıdır. Kurumun işlerini fiilen yönetmenin ne anlama geldiği, kimlerin faaliyetleri fiilen yönetiyor sayılacağı, yönetim yetkisinin kapsamı, doğal olarak, Yönerge'de belirtilmemiştir. Bu konuyu her Üye Devlette ve belki kredi

${ }^{24}$ 86/635/EEC sayılı yönergenin "Yedek Akçeler" başlığını taşıyan 23. maddesinde gönderme yapılan 78/660/EEC sayılı Dördüncü Konsey Yönergesi'nin 9. maddesine göre yedek akçeler, i) ulusal hukukun gerekli kıldığı kanunî yedek akçeleri, ii) 77/91/EEC sayılı yönergenin 2 (1) (b) maddesi saklı kalma koşuluyla, ulusal hukukun gerekli kıldığı ölçüde sermaye payları için ayrılan yedek akçeleri, iii)ana sözleşmede öngörülen yedek akçeleri ve iv) diğer yedek akçeleri içerir. 
kurumlarının türlerine göre sınıflandırarak ulusal hukukların düzenlemesi gerekir. Kredi kurumunun yönetiminden sorumlu olan kişilerin yeterince iyi şöhrete ve görevlerini yerine getirmek için gereken deneyime sahip olmaları, faaliyet izni verilirken aranan bir başka koşuldur. Yöneticilerde bulunması gerekli sayılan söz konusu niteliklerin ölçütleri de, hiç kuşkusuz, ancak ulusal düzenlemelerle belirlenebilir.

4. Yönerge'nin 12. maddesine göre kredi kurumları, ister gerçek isterse tüzel kişi olsun, sermayelerinde doğrudan ya da dolaylı biçimde nitelikli pay'a (qualifying holding) sahip bulunan tüm hissedarların kimlikleri ile ellerindeki hisselerin tutarlarını yetkili mercilere bildirmedikçe faaliyet izni alamazlar. Yetkili merciler, bu hissedarların niteliklerini kredi kurumunun sağlıklı ve basiretli yönetimi bakımından uygun ve yeterli görmezlerse, faaliyet izni almak için yapılan başvuruyu geri çevirmekle yükümlüdürler. Yönerge'nin 4. maddesinin 11. bendinde nitelikli sermaye pay1, bir teşebbüste sermayenin ya da oy haklarının \%10'unu veya daha fazlasını doğrudan doğruya ya da dolaylı biçimde temsil eden yahut teşebbüsün yönetimini önemli ölçüde etkilemeye olanak veren sermaye payı olarak tanımlanmıștır. Nitelikli sermaye payını saptarken 2001/34/EC sayılı yönergenin ${ }^{25}$ "Oy Haklarının Belirlenmesi" başlıklı 92. maddesinin göZ önünde tutulması gerekmektedir. Bu maddede bir kişinin oy hakkını elinde bulundurduğu kabul edilen sekiz durum gösterilmiştir. Yönerge, 4. madde nitelikli sermaye payını tanımlarken de jure sahip olunan yetki ile yetinmeyip, yönetimi önemli ölçüde etkileme olanağı gibi de facto durumu da dikkate almıştır. Bunun nedeni, hukuken ya da fiilen sahip oldukları güçle kredi kurumunun yönetimini etkileyebilecek konumda olanların gerek kimliklerinin gerekse niteliklerinin büyük önem taşımasıdır. Gerçekten de, nitelikli sermaye payına sahip olanların ellerindeki gücü kötüye kullanmayacaklarına öteki ortaklar, kredi kurumunun alacaklıları ile gözetim ve denetimden sorumlu olan yetkili merciler güvenebilmeli; kredi kurumu malî güçlüklerle karşılaştığında nitelikli pay sahiplerinin ilk desteği sağlayabilecek olanakları olmalıdır. Ayrıca, söz konusu ortağın ya da ortakların kredi kurumu olması durumunda, aynı piyasada faaliyet gösteren, dolayısıyla aynı risklerin etkisine açık olan kredi kurumlarında nitelikli sermaye payına sahip olunması sistemik krizlerin ortaya çıkma olasılığını çok arttırır; kredi kurumları arasında çapraz pay sahipliği (crossshareholding), özellikle de piyasanın krizle karşılaştığı durumlarda, çıkar çatışmalarına yol açabilir; üstelik çapraz pay sahipliği, kredi kurumları piyasasında rekabetin sinırlanmasına, oligopolcü eğilimlerin ve uygulamaların ortaya çıkmasına neden olabilir. Buna karşıllk, Yönerge'de öngörüldüğü gibi uygun ve yeterli biçimde denetlenebilirse çapraz pay

${ }^{25}$ Directive 2001/34/EC of the European Parliament and of the Council of 28 May 2001 on the admission of securities to official stock exchange listing and on information to be published on those securities, OJ L184 06.07.2001, sh.1-60. 
sahipliği, kredi kurumlarının etkinliğini ve kârlılığını arttırıcı sonuçlar yaratabilir. Bu yüzdendir ki, Avrupa Birliği düzenlemelerinde çapraz pay sahipliğini kesinlikle yasaklama yoluna gidilmemiş, fakat gözetim ve denetim altında tutulabilmesi için, nitelikli sermaye payı sahiplerinin yetkili mercilere bildirilmesi zorunluluğuna yer verilmiştir. ${ }^{26}$ Öte yandan, kredi kurumu ile bir başka gerçek ya da tüzel kişi arasında yakın ilişsiler bulunuyorsa yetkili mercilerin faaliyet izni verebilmeleri, bu ilişkilerin etkin bir gözetim ve denetim uygulamasını engellemediğine kanaat getirmelerine bağlıdır; özellikle, kredi kurumu ile arasında yakın ilişkiler bulunan gerçek ya da tüzel kişi veya kişilerin tâbi oldukları üçüncü bir ülkenin kanunları, tüzükleri ya da idarî düzenlemeleri yahut bunların uygulanmasında karşılaşılabilecek güçlükler etkin bir gözetim ve denetimin gerçekleştirilmesini engelliyorsa yetkili merciler faaliyet izni veremezler. Bir başka gerçek ya da tüzel kişiyle aralarında yakın ilişsiler bulunan kredi kurumları, etkin bir gözetim ve denetimin engellenmediğini izlemeye yardım edecek bilgileri yetkili mercilere sürekli olarak vermek ile yükümlüdürler; ancak, yakın ilişkiler deyiminin nitelikleri Yönerge' de belirlenmemiştir.

Farklı Üye Devletlerde kurulmuş kredi kurumları arasında ilişki söz konusu olduğunda Yönerge'nin sermaye iştirakinin denetimine daha fazla önem verdiği gözlemlenmektedir. Yönergenin 15. maddesinin 1. bendine göre, faaliyet izni almak üzere baş vuran kredi kurumu,

a) bir başka Üye Devlette faaliyet izni verilmiş olan bir kredi kurumunun yavru kuruluşu ise;

b) bir başka Üye Devlette faaliyet izni verilmiş olan bir kredi kurumunun bağlı bulunduğu ana teşebbüsün yavru kuruluşu ise;

c) yönetiminde egemen olan, gerçek ya da tüzel, aynı kişiler bir başka Üye Devlette faaliyet izni verilmiş olan bir kredi kurumunun yönetiminde de egemen durumda ise;

yetkili mercilerin, faaliyet izni vermeden önce ilgili Üye Devletin yetkili mercilerinden görüş istemeleri zorunludur.

Aynı şekilde, faaliyet izni almak üzere baş vuran bir kredi kurumu,

a) Topluluk'da faaliyet izni almış bir sigorta teşebbüsünün ya da malî yatırım firmasının yavru kuruluşu ise;

b) Topluluk'da faaliyet izni almış bir sigorta teşebbüsünün ya da malî yatırım firmasının bağlı bulunduğu ana kuruluşun yavru kuruluşu ise;

c) yönetiminde egemen olan, gerçek ya da tüzel, aynı kişiler Topluluk'da faaliyet izni almış olan bir sigorta teşebbüsünün ya da malî yatırım firmasının yönetiminde de egemen durumda ise;

\footnotetext{
${ }^{26}$ Bk. M. DASSESSE ve diğ.: a.g.e sh.115.
} 
yetkili mercilerin, faaliyet izni vermeden önce ilgili Üye Devlette sigorta teşebbüslerinin ve malî yatırım firmalarının gözetim ve denetiminden sorumlu olan yetkili mercilere danışması ve görüş istemesi zorunludur.

İlgili Üye Devletlerdeki yetkili mercilerin, özellikle ortakların niteliklerini, yöneticilerin yeterli deneyime ve iyi şöhrete sahip olup olmadıklarını değerlendirirken görüş alış-verişi yapmaları, birbirlerine danışmaları gerekmektedir. Yapılan bu danışmadan olumlu sonuç çıkmazsa, 12. maddenin 3. bendine göre faaliyet izni verilmeyecektir. Ortakların ya da yöneticilerin nitelikleri dişında kalan bir konuda olumsuz görüş bildirildiğinde nasıl bir yol izleneceği Yönerge'de belirtilmemiştir. Bu boşluğu Üye Devletler, iç hukuklarında yapacakları ek düzenlemelerle doldurabileceklerdir.

Yönetimde egemen olma (control) deyimi Yönerge'nin 1. maddesinin 9. bendinde, "bir ana teşebbüs ile yavru kuruluş arasında 83/349/EEC sayılı yönergenin 1. maddesinde tanımlanmış bulunan ilişki ya da her hangi bir gerçek ya da tüzel kişi ile bir teşebbüs arasındaki benzer ilişki" olarak ifade edilmiştir. ${ }^{27}$ Yavru kuruluş (subsidiary) deyimi ise, Yönerge'nin yine 1. maddesinin 13. bendine göre, 83/349/EEC say1lı yönergenin 1. ve 2. maddelerinde tanımlanmış olan bir yavru teşebbüsü ya da 71,72,73. maddeler ile Anabölüm V'in 2. ve 4. bölümleri açısından 83/349/EEC sayılı yönergenin 1. maddesinde tanımlanan yavru teşebbüsü ve ana kuruluşca üzerinde güçlü bir etki yapıldığı yetkili mercilerce kabul edilen her hangi bir teşebbüsü ifade eder. Yavru teşebbüsün tüm yavru kuruluşları da ana kuruluş olan teşebbüsün yavru kuruluşu sayılmaktadır.

5. Kredi kurumunun, izin almak için yaptığ programının eklenmesi gerekmektedir. Yönerge'nin 7. maddesine göre bu program, öteki konular arasında, yapılması öngörülen işlerin türlerine ve kredi kurumunun yapısal örgütlenmesine ilişkin açıklamaları da içerecektir. Programın, ayrıca, kurumun faaliyet göstereceği coğrafî alan, kullanacağı olanaklar, teknikler ve çalıştıracağı personel gibi konuları da kısa ve uzun

${ }^{27}$ Seventh Council Directive 83/349/EEC of 13 June 1983 based on the Article 54 (3) (g) of the Treaty on consolidated accounts, OJ L 193 18.07.1983, sh.1-17. Yönergenin 1. maddesine göre bir teşebbüs, a) bir başka teşebbüste (yavru kuruluş) hissedarlara ait oy haklarının çoğunluğuna sahipse ya da b) bir başka teşebbüste (yavru kuruluş) hissedar olup da yönetim kurulunun, yöneticilerin ya da denetçilerin çoğunluğunu atama veya görevden alma yetkisine sahipse ya da c) yavru kuruluşun tâbi olduğu hukukun izin vermesi koşuluyla, hissedarı olduğu teşebbüs (yavru kuruluş) ile yaptığı bir sözleşmeye ya da anasözleşmedeki bir hükme dayanarak o teşebbüs üzerinde güçlü bir etki yaratabilme hakkına sahipse ya da d) bir teşebbüsün hissedarı olup da aa) içinde bulunulan malî yılda, bir önceki malî yılda ve konsolide hesapların düzenlendiği tarihe kadar o teșebbüste (yavru kuruluş) görev almış olan yönetim kurulunun, yöneticilerin veya denetçilerin çoğunluğunu, sahip bulunduğu oy haklarını kullanarak, tek başına atamış ise ya da bb) o teşebbüsün (yavru kuruluş) öteki hissedarları ile yaptığı bir sözleşmeye dayanarak oy haklarının çoğunluğunu tek başına kullanabiliyorsa, yavru kuruluşun bağlı bulunduğu ana kuruluş sayılır. 
vâde ayırımı yaparak belirtmesi uygun olur. Ancak, Yönerge'nin faaliyet programını yapılabilirlik çalışması niteliğinde gördüğü söylenemez. $\mathrm{Bu}$ program, daha çok, yetkili makamların başlangıçtaki gözetim ve denetim görevlerini yerine getirirken yararlanabilecekleri bir metin olmalıdır. Nitekim Yönerge'nin önsözünün 10. bendinde, faaliyet programlarının içeriğinden, faaliyetlerinin coğrafî̀ dağılımından ve fiilen yaptığı faaliyetlerden, bir Üye Devletteki daha sik1 ya da daha k1sitlayıc1 düzenlemelerden kaçınmak amacıyla bir başka Üye Devlette faaliyet izni almak için başvuruda bulunduğu açıkca anlaşılan kredi kurumlarına bu iznin verilmeyeceği, verilmişse geri alınacağı ifade edilmiştir. Buna karşılık, Yönerge' nin 22. maddesine göre yetkili merciler, faaliyet izni verdikleri her kredi kurumunun iyi tanımlanmış, şeffaf ve tutarlı sorumluluk alanlarının; karşılaşılan ya da karşılabilecek riskleri teşhis etmek, yönetmek, izlemek ve rapor etmek için etkin usullerin; sağlıklı muhasebe ve idare uygulamalarını da kapsayan yeterli iç kontrol mekanizmalarının belirtildiği açık-seçik bir örgütsel yapıyı içeren güçlü yönetişim düzenlemeleri yapmalarını sağlamakla yükümlüdürler. Hiç kuşkusuz bu düzenlemeler, usuller ve mekanizmalar, kredi kurumunun faaliyetlerinin niteliği, kapsamı ve karmaşıklık derecesi ile orantılı olacaktır.

6. Ülkede kurulacak kredi kurumları, 2006/48/EC sayılı yönergede yer alan gerekliliklere ek olarak Üye Devletlerin ulusal düzenlemelerinde serbestçe belirleyebilecekleri koşullara da uymak zorundadırlar. Faaliyet izni verilmesine ilişkin olarak Yönergede yer alan kuralları Üye Devletlerin ağırlaştırmasına, ek koşullar koymasına bir engel yoktur, ${ }^{28}$ ancak bunların Komisyon'a bildirilmesi ve genel nitelikli olması; bir başka deyişle, bir kredi kurumundan ötekine fark göstermemesi gerekir. Bununla birlikte ek kuralların, tek tek kredi kurumları için farklı olamasalar da, belli kredi kurumu türlerine göre değişiklik gösterebilecekleri söylenebilir. Hiç kuşkusuz, bir Üye Devletin ülkesinde kurulmuş olan kredi kurumları için ek kurallar koyması, daha yüksek normlar ve standartlar kabul etmesi öteki Üye Devletlerde faaliyet izni almış olan kredi kurumlarına rekabet üstünlüğü sağlar ve her halde Üye Devletlerin bu yola kolayca gidebilecekleri söylenemez. Bununla birlikte, Adalet Divan1, tersine ayırım (reverse discrimination) yaratan bu gibi uygulamaları Roma Antlaşması'nın ilkelerine aykırı sayan bir karar vermemiștir. Ülkesinde kurulan kredi kurumlarına ilişkin olarak ek kurallar koyan Üye Devlet, merkezi bir başka Üye Devlette olup da ülkesinde şube açmak ya da sınır ötesi hizmet sunmak isteyen kredi kurumlarının, Yönerge'deki koşulları yerine getirmişlerse, ek koşullara da uymalarını zorunlu kılamaz.

${ }^{28}$ 2006/48/EC sayılı yönergenin önsözünün 15. bendinde "Üye Devletler, yetkili mercilerin faaliyet izni verdiği kredi kurumları için, 9. maddenin 1. bendinin ilk fıkrasında, 9. maddenin 2. bendinde ve 12. maddesinde, 19'dan 21.'ye, 44'den 52.'ye kadar olan maddelerde, 75. maddede ve 120'den 122.'ye kadar olan maddelerde konmuş bulunanlardan daha sıkı kurallar kabul edebilirler." ifadesi yer almaktadır. 
Yönerge'nin hükümleri, faaliyet izni almak isteyen kredi kurumlarınca yerine getirilmesi gereken genel nitelikli ek koşullar koyma serbestisini Üye Devletlere tanımışsa da yapılan başvurunun, piyasanın ekonomik gereksinmeleri açısından incelenmesini yasaklamıștır; dolayısıyla başvuru, piyasanın ekonomik açıdan yeni bir kredi kurumuna gereksinmesi olmadığı gerekçesiyle geri çevrilemez. Faaliyet izninin verilmesi ile piyasanın ekonomik gereksinmesi arasında bir bağ kurulması, Üye Devletlere geniş bir takdir yetkisi verir; oysa 2006/48/EC sayılı yönerge, gözetim ve denetim mercilerinin faaliyet izni verme konusundaki takdir yetkilerini elden geldiğince sınırlamayı; saptadığı niteliklere sahip olan kredi kurumlarının piyasaya olabildiğince çok sayıda girerek rekabete katılma olanaklarını arttırmayı amaçlamaktadır.

Üye Devletlerin yetkili mercilerince kredi kurumlarına verilen faaliyet izinlerinin Komisyon'a bildirilmesi ve faaliyet izini alan kredi kurumlarını gösteren bir listenin Komisyonca düzenlenip sürekli güncelleştirilerek Resmî Gazete'de yayınlanması Yönerge'nin 14. maddesi gereğidir. ${ }^{29} \mathrm{Ne}$ var ki, Üye Devletlerin yetkili mercilerince iletilen bilgilere dayanılarak düzenlenen bu listeye kaydedilmek ya da kaydedilmemek her hangi bir hukukî sonuç doğurmamaktadır. Faaliyet izni almamış olmasına karşın yanlışlıkla listeye kaydedilen bir teşebbüs, salt bu nedenle kredi kurumu niteliğini kazanamaz. Aynı şekilde, faaliyet izni almış olmakla birlikte listeye kaydedilmeyen teşebbüsler de kredi kurumu olma niteliğini yitirmezler.

7. Yönerge'nin 11. maddesine göre, tüzel kişiliği olan kredi kurumları, eğer ülkede bir tescil mercii varsa, genel merkezlerini tescil merciinin bulunduğu Üye Devlette açacaklardır; tüm öteki kredi kurumlarının genel merkezleri ise, faaliyet iznini vermiş olan ve işlerini fiilen yürüttükleri Üye Devlette bulunacaktır.

Kredi kurumlarının faaliyet izni alabilmek için yaptıkları başvuruyu kabul etmeyip geri çeviren yetkili merciler kararlarını gerekçeli olarak vermek zorundadırlar. Yönerge'nin 13. maddesine göre yetkili mercilerin kararları, başvurunun alındığ günü izleyen altı ay içinde; başvuruda eksiklik varsa, eksikliğin tamamlandığı tarihten başlayarak altı ay içinde kredi kurumuna bildirilecektir. Kararın, her halde, başvurunun yapılmasından sonraki oniki ay içinde alınması zorunludur.

VIII. Tek Bankacılık Lisansı: Birinci Bankacılık Yönergesi'nin 4. maddesi, merkezi bir Üye Devlette bulunan kredi kurumlarınca bir başka Üye Devlette açılmak istenen şubelerin, ülkesinde kurulmuş kredi kurumlarına uygulanmakta olan kanunlara ve usullere uyarak önceden

${ }^{29} \mathrm{Bu}$ listenin örnekleri için bk.List of credit institutions provided for in Articles 3 (7) and 10(2) of Directive 77/780/EEC, (90/C 107/10) OJ C 107 30.04.1990, sh.1 vd.; List of credit institutions provided for in Article 2000/12/EC (Situation as at 31 December 2002) Twenty-first version, OJ C 290 01.12.2003, sh.1-311. 
faaliyet izni almalarını zorunlu kılma yetkisini ilgili Üye Devlete vermekteydi. İkinci Bankacılık Yönergesi çıkarılıp uygulanıncaya kadar geçen süre içinde yürürlükte kalan bu hüküm gereğince, Üye Devletlerin birinde kurulmuş ya da faaliyet izni almış kredi kurumları, bir başka Üye Devlette ancak yeni kurulacak kredi kurumlarının tâbi oldukları kurallara ve usullere uyma koşuluyla şube açabiliyorlardı. Bu uygulama, çeşitli olumsuzluklar yaratarak bir başka Üye Devlette şube açılmasını zorlaştırıyor, dolayısıyla kredi kurumları arası rekabetin Topluluk ölçeğinde yaygınlaşmasını engelliyordu. Söz konusu olumsuzlukların başta geleni, kredi kurumlarının merkezleri ile öteki Üye Devletlerin her birinde açtıkları şubelerin, değişik boyutlarda zaman, emek ve para harcanmasını gerektiren, aralarında az-çok fark bulunan gözetim ve denetim sistemlerine tâbi olmalarıydı. Bu zorunluluk, şubelerce üstlenilen gözetim ve denetim yükünü, dolayısıyla işlem maliyetlerini arttırıyordu. Ayrıca şubelere, faaliyet gösterdikleri Üye Devletlerde yeni kurulacak kredi kurumlarının sahip olmaları gereken asgarî özkaynak kadar sermaye (endowment capital) tahsis edilmesi zorunlu tutuluyordu. $\mathrm{Bu}$ gereklilik de, kredi kurumunun özkaynaklarını şubeler arasında dağıtarak hem özkaynak gereksinmesini arttırıyor, hem de özkaynaklarla ilişkilendirilmiş olan kredi açma gücünü zayıflatıyordu. Öte yandan kredi kurumlarının, kendi ülkelerinde yasaklanmamış ya da açıkca izin verilmiş fakat öteki Üye Devletlerde aynı serbestiden yararlanamayan bazı işlemleri şube açtıkları ülkelerde yapmaları söz konusu olamıyordu. Bu nedenlerledir ki, İkinci Bankacılık Yönergesi uygulanıncaya kadar geçen süre boyunca kredi kurumlarının öteki Üye Devletlerdeki faaliyetleri yeteri kadar genişleyememiştir; oysa, tüketicilerin, küçük işletmelerin ve tasarruf sahiplerinin daha elverişli bankacılık koşullarından yararlanabilmeleri, kredi kurumları arasındaki rekabetin gerekli düzeye erişmesine bağlıdır. Nitekim, Toplulukta oluşturulmak istenen kredi kurumları tekpazarının bir amacı da perakendeci bankacılık (retail banking) hizmetlerinde rekabeti arttırmaktır. Geleneksel olarak perakende bankacılık hizmetleri, kredi kurumunun kurulduğu Üye Devletteki müşterilere yöneliktir. Ülkedeki firmalara ve bireylere sunulan bu hizmetler tüketici kredisi, ipotekli kredi ve ticarî kredi verme, para gönderme ve ödeme, kredi kartları, döviz ve seyahat çekleri satışı, akreditif açma gibi işlemlerdir. ${ }^{30} \mathrm{Bu}$ dönemde kredi kurumları, genellikle, öteki Üye Devletlerde perakende bankacılık hizmetleri sunacak şubeler açma yerine, büyük kurumsal müşteriler ile kamu kesimine malî hizmet sağlayan az sayıda yurtdışı şube açarak toptancı bankacılık (wholesale banking) yapma yoluna gitmişlerdir. Ne var ki, toptancı bankacılık alanındaki uluslararası rekabet zaten şiddetli cereyan ettiğinden, kredi kurumlarının bu tutumu amaçlanan sonuçların elde edilmesine önemli bir katkıda bulunmamıştır. Üstelik,

${ }^{30}$ Gary C.ZIMMERMAN: Implementing the Single Banking Market in Europe, Federal Reserve Bank of San Francisco (FBRSF) Economic Review, 1995 No:3, sh.36. 
toptancı bankacılık faaliyetleri giderek az sayıdaki malî merkezlerde yoğunlaşma eğilimi göstermiştir. ${ }^{31}$

İkinci Bankacılık Yönergesi, bir Üye Devlette faaliyet izni almış olan kredi kurumlarının özel bir izne gerek olmaksızın öteki Üye Devletlerde şube açmalarına ya da sınır ötesi hizmet sunmalarına olanak sağlayarak; gerek kendi ülkelerinde gerekse şube açtıkları ya da sınır ötesi hizmet sundukları Üye Devletlerde yaptıkları faaliyetlerin gözetim ve denetim sorumluluğunu, merkezlerinin bulunduğu Üye Devletteki, bir başka deyişle faaliyet izninin verildiği ülkedeki yetkili mercilere aktararak (home country control principle) ve açılan şubelere sermaye tahsisi zorunluluğunu kaldırarak, sözü edilen sakıncaları büyük ölçüde azaltmıştır. ${ }^{32}$ İkinci Bankacılık Yönergesi'nin getirdiği bu değişiklikler arasında kredi kurumları tekpazarının oluşumu bakımından son derece önemli olanı, kredi kurumlarının ülkelerindeki yetkili mercilerden aldıkları faaliyet iznine dayanarak ve başkaca bir izin almaya gerek olmaksızın tüm öteki Üye Devletlerde şube açabilmeleri ya da sınır ötesi hizmet sunabilmeleridir.Yetkili mercilerden alınan faaliyet izni, tüm Üye Devletlerde geçerli olduğu ve gerek sınır ötesi hizmet sunma gerekse şube açma olanağını bir arada sağladığı için, daha önce de belirtildiği üzere, Tek Bankacılık Lisansı olarak adlandırılmaktadır. İkinci Bankacılık Yönergesi ile getirilen bu düzenleme, bugün yürürlükte olan 2006/48/EC sayılı yönergede de yer almaktadır. Bununla birlikte her Üye Devlet, kuruldukları Üye Devletlerde kredi kurumu olarak faaliyet izni almış kurumların ayrıca izin almaya gerek olmaksızın ülkesinde şube açıp yerleşmelerine ve hizmet sunmalarına engel olamazsa da, bu hakları kullanmalarına ve Yönerge'ye bağlı EK I'de yer almayan faaliyetleri yapmalarına ilişkin olarak, kendi ulusal düzenlemelerine özel hükümler koyma ve bunlara uyulmasını zorunlu kılma yetkisini halâ elinde bulundurmaktadır. Buna göre, kredi kurumları, ayrı bir izin almaksızın şube açabildikleri ya da hizmet sunabildikleri ülkelerde, kendi ülkelerinde yapabilecekleri fakat öteki Üye Devletlerde izin verilmeyen işlemleri yapamazlar; örneğin, kredi kurumlarının taşınmaz mal ticareti ile uğraşan gerçek ve tüzel kişilere kredi vermelerini yasaklayan bir Üye Devlette, kendi ülkelerinde izin verilen bu tür işlemleri, şube açarak veya sinır ötesi hizmet sunarak yapamazlar. Ne var ki, ulusal hukuka konan özel hükümlerin uyrukluk, ikamet yeri, kurumun hukukî şekli gibi konularda ayırımcı olmaması, Topluluk düzenlemeleri ile uyumlu ve genel iyiliği (general good) korumaya yönelik olması, ayrıca, söz konusu kurumların ya da faaliyetlerin ilgili Üye Devletlerdeki ve Topluluktaki eşdeğer kurallara

${ }^{31}$ Bk. Wim FONTEYNE: EU:From Monetary to Financial Union, Finance and Development, June 2006 vol:43 No:2.

32 İkinci Bankacılık Yönergesi’nin yürürlüğe girdiği 1 Ocak 1993 tarihini izleyen üç yılda Üye Devletlerdeki kredi kurumlarının öteki Üye Devletlerde açtıkları şube sayısı \% 58 artış göstermiştir. Bk.European Commission Single Market News, No:4 June 96; ec.europa.eu/internal market/smn/smn04. 
tâbi bulunmaması gerekir. Genel iyilik kavramı 2006/48/EC sayılı yönerge gibi öteki yönergelerde de tanımlanmamıştır. ${ }^{33}$ Ulusal düzenlemelere konan hükümlerin gerek Topluluk hukukuna gerekse genel iyiliğe uygunluğu, hiç kuşkusuz, Adalet Divanı'nın denetimi altındadır.

Kredi kurumlarının yurtdışında yapabilecekleri faaliyetler bakımından, şube açtıkları ya da sınır ötesi hizmet sundukları Üye Devletin belli nitelikteki ulusal düzenlemelerine tâbi olmalarının önemli bir istisnası 2006/48/EC sayılı yönergenin 23. maddesinde yer almaktadır. İkinci Bankacılık Yönergesi ile 2000/12/EC sayılı yönergelerin 18. maddelerinde de benzerlerine yer verilmiş olan bu maddeye göre Üye Devletler, bir başka Üye Devletin yetkili mercilerinden faaliyet izni almış ve bu mercilerin gözetim ve denetimi altında bulunan kredi kurumlarının, ülkelerinde şube açma veya hizmet sunma suretiyle EK I'deki listede sıralanan işlemleri yapmalarını engelleyemezler; ancak bu serbestiden yararlanabilmesi için, söz konusu işlemleri yapabileceği kredi kurumuna verilen faaliyet izninde belirtilmiş olmalıdır.

2006/48/EC sayılı yönergenin yukarda anılan 23. maddesine göre Topluluktaki kredi kurumları,

a) merkezlerinin bulunduğu Üye Devletlerin yetkili mercilerinden Avrupa Birliği'nin konuya ilişkin yönergelerinin gereklerini yerine getirerek faaliyet izni almışlarsa ve bu mercilerce yine ilgili yönergelere göre uygulanan gözetim ve denetime tâbi iseler; ayrica,

b) yetkili mercilerden aldıkları faaliyet izninde, Yönerge'nin Karşılıklı Tanımaya Tâbi Faaliyetler Listesi başlığını taşıyan 1 numaralı Ek'inde sayılan işlemlerin bazılarını ya da tümünü yapabilecekleri belirtilmişse;

sözü edilen listede yer verilmiş olan işlemlerden faaliyet izninde gösterilmiş olanları, şube açtıkları ya da hizmet sundukları tüm öteki Üye Devletlerde, o ülkelerde ulusal kredi kurumlarına yasaklanmış da olsa, ayrıca bir izin almaya gerek olmaksızın ve her hangi bir engelle karşılaşmaksızın, şube açma ya da hizmet sunma yoluyla serbestçe yapabilirler; başka bir deyişle Üye Devletler, genel iyiliği sağlama amacıyla koymuş da olsalar ulusal hukuklarında bulunan kuralları uygulayarak bu işlemlerin yapılmasını kısitlama ya da yasaklama yoluna gidemezler. ${ }^{34}$ Kredi kurumları, 2006/48/EC sayılı yönergenin 1 numaralı ekinde yer almış olan işlemlerden

${ }^{33}$ Komisyon, 1997 yılında yayınladığı bir bildiride genel iyiliğe yönelik kuralların, a) daha önce Topluluk' da yapılmış uyumlulaştırma çalışmalarının konusu olmaması; b) ayırımcılık yapmaması; c) tüketicinin korunmas1, sahteciliğin önlenmesi,vergi sisteminin tutarlıllğ̆ gibi genel iyiliğe yönelik amaçların haklı kılmış olması; d) kredi kurumunun geldiği Üye Devletteki kuralların bir tekrarı olmaması; e) nesnel açıdan gerekli ve izlenen amaçla orantılı olması gibi nitelikler taşıması hususlarına işaret etmiştir Bk. http://europa.eu.int/ en/comm/dg15/dg15home.html.

${ }^{34}$ M.DASSESSE: a.g.e. sh.37. 
bazılarını ya da tümünü, faaliyet izinlerinde belirtilmesi koşuluyla, gerek yurtiçinde gerekse şube açtıkları ya da sınır ötesi hizmet sundukları tüm Üye Devletlerde, ayrıca her hangi bir izin almaksızın, serbestçe yapabilirler.

23. madde hükmü de göz önüne alınarak Tek Bankacılık Lisansı'nın uygulanmasına ilişkin üç durum ayırt edilebilir. ${ }^{35}$ İlkin, yukarda açıklandığı üzere, kurulduğu ülkedeki yetkili mercilerden aldığı faaliyet izninde Yönerge'nin 1 numaralı ekinde sayılan işlemlerden bazılarını veya tümünü yapabileceği belirtilmiş olan kredi kurumu bu işlemleri, başka bir izin alma gereksinmesi olmadan, her Üye Devlette şube açarak ya da sınır ötesi hizmet sunarak ve o ülkelerde kurulmuş olan kredi kurumlarına yasaklanmış da olsa, yapma yetkisine sahiptir. Yönerge ekindeki işlemlerden bazılarını ya da tümünü yapamayacağını ulusal yetkili mercilerin faaliyet izninde açıkca belirttiği ikinci durumda kredi kurumu, yine yerleşme ve sınır ötesi hizmet sunma haklarından yararlanarak, Topluluğun her yerinde izin almaksızın şube açabilir; hizmet sunabilir; fakat, Yönerge ekinde yer alan faaliyetlerden izin verilmemiş olanları yapamaz. Üçüncü durumda, yetkili mercilerin sadece Yönerge ekinde yer almayan bir işlemi belirterek faaliyet izni verdiği kredi kurumu, yine her hangi bir ek izne gerek olmaksızın Topluluğun her yerinde şube açabilir; hizmet sunabilir; fakat kendisine izin verilen faaliyeti, ancak, gittiği Üye Devletteki hukuk düzenlemesinin kurallarına göre yapabilir.

Tek Bankacılık Lisansı, Karşılıklı Tanıma İlkesi (Mutual Recognition Principle) ile Köken Devletin Denetimi Illkesi (Home Country Control Principle), başka bir deyişle, Kredi Kurumlarının Gözetim ve Denetiminin Faaliyet İznini Veren Üye Devlet Yetkili Mercilerine Ait Olması İlkesi'nin yarattığı doğal sonuçtur. Genel bir tanımla karşılıklı tanıma ilkesi, bir Üye Devlette yetkili mercilerin yürürlükteki hukukî düzenlemelere uygun olarak verdiği bir kararın, saptadığı bir olgunun, belirlediği standardın veya normun ya da düzenlediği bir belgenin öteki Üye Devletlerin yetkili mercilerince tartışmasız olarak geçerli sayılmasıdır. Kredi kurumlarını ilgilendirdiği ölçüde karşılıklı tanıma ilkesi, her Üye Devletdeki yetkili mercilerin bankaların gözetim ve denetime ilişkin kendi ulusal düzenlemeleri ile öteki Üye Devletlerdeki düzenlemeleri özdeş olmasalar da eşdeğer nitelikte kabul etmeleridir. Karşılıklı tanımanın uygulamadaki sonucu, Üye Devletlerde bankaların gözetim ve denetiminden sorumlu mercilerin, öteki Üye Devletlerden gelerek ülkelerinde şube açan ya da sınır ötesi hizmet sunan kredi kurumlarına kendi kanunlarını, tüzüklerini, idarî düzenlemelerini uygulama hakkından feragat etmesidir. $\mathrm{Bu}$ vazgeçmenin nedeni, kredi kurumlarının üzerindeki gözetim ve denetimin faaliyet iznini vermiş olan Üye Devletin, başka bir deyişle Köken Devletin yetkili mercilerince, belki farklı biçimde fakat eşdeğer güvenliği sağlayacak yöntemlerle yapıldığının ya da yapılacağının kabulüdür. Köken Devletin Denetimi İlkesi'ne göre, her

\footnotetext{
${ }^{35}$ y.a.g.e. sh. $34 \mathrm{vd}$.
} 
Üye Devlette faaliyet iznini vermiş olan merciler, ülkelerinde kurulmuş olan kredi kurumlarının salt yurtiçindeki değil, aynı zamanda şube açarak ya da sınır ötesi hizmet sunarak tüm öteki Üye Devletlerde yapacakları faaliyetler üzerinde de münhasır bir gözetim ve denetim yetkisine sahiptirler. Köken Devletin Denetimi İlkesi, Topluluk'da bankacilık hizmetlerinin serbestleştirilmesinin bir aracı olduğu kadar, bankalar üzerindeki gözetim ve denetimin Topluluk ölçeğinde birlik ve tutarlılık kazanmasını sağlamanın da yöntemidir. ${ }^{36}$ Gerek karşılıklı tanıma ilkesinin gerekse köken Devletin denetimi ilkesinin uygulamaya geçirilebilmesi için Üye Devletlerde kredi kurumlarının gözetim ve denetimine ilişkin düzenlemelerin, hiç olmazsa belirli bir ölçüde uyumlulaştırılması ve yetkili merciler arasında danışma ve işbirliği kanallarının kurulması gereklidir. Kredi kurumlarının kuruldukları ülkelerde ve Topluluğun her yerinde yaptıkları faaliyetler, kendilerine izin vermiş olan yetkili mercilerin gözetim ve denetimine tâbi olacağına göre bu mercilerden alınmış olan faaliyet izninin de Topluluğun her üyesinde tartışmasız geçerli olması gerekir.

2006/48/EC sayıl1 yönergenin 23. maddesinin gönderme yaptığı ve Karşılıklı Tanımaya Tâbi Faaliyetler Listesi başlığını taşıyan 1 numaralı eki, geniş bir işlemler yelpazesini içermektedir. Listede aşağıdaki işlemler yer almaktadir:

1. mevduat ve geri ödenmek üzere başka türden fonlar kabul etme; 2. diğerlerinin yanı sıra tüketici kredisini, ipotek karşılığ krediyi, rücu edilebilen ve rücu edilmeyen factoringi ve ticarî işlemlerin finansmanını (forfaiting dahil) da içermek üzere, tüm borç verme işlemleri; 3. finansal kiralama; 4. para aktarma (havale) hizmetleri; 5. kredi kartları, yolcu çekleri, banka çekleri gibi ödeme araçlarının ihracı ve yönetimi; 6 . garanti ve taahhüt işlemleri; 7. kendi hesabına ya da müşteriler hesabına olmak üzere, a) çekler, poliçeler, mevduat sertifikaları gibi para piyasası araçları, b) döviz; c) vâdeli finansal sözleşmeler (futures) ve option sözleşmeleri; d) döviz ve faiz oranları ile ilişkili malî araçlar; e) devir edilebilir menkul kıymetler ile ilgili işlemler; 8. hisse senedi ihracına katılma ve hisse senedi ihracına ilişkin hizmetler sunma; 9. teşebbüslere sermaye yapısı, sınaî strateji ve bunlarla ilgili sorunlar konusunda danışmanlık; şirket birleşmelerine ve şirket satın alımına ilişkin danışmanlık ve hizmet sunumu; 10. para piyasasında simsarlık; 11. portföy yönetimi ve danışmanlığı; 12. menkul kıymetleri saklama ve yönetme; 13. kredi referans hizmetleri; 14. saklama (kiralık kasa) hizmetleri. Ayrıca, “Avrupa Parlâmentosu'nun ve Konsey’in Malî Araçlar Piyasalarına İlişkin 2004/39/EC sayılı ve 21 Nisan 2004 tarihli Yönergesi”ne ${ }^{37}$ bağlı EK I'in C bölümünde gösterilen malî araçlara gönderme yapıldığında, aynı EK'in A ve B ölümlerinde yer alan hizmetler

\footnotetext{
${ }^{36}$ y.a.g.e. sh. 26 .

${ }^{37}$ Directive 2004/39/EC of the European Parliament and of the Council of 21 April 2004 on markets in financial instruments, OJ L 145 30.04.2004, sh.1.
} 
ve faaliyetler de 2006/48/EC sayılı yönerge anlamında karşılıklı tanımaya tâbidir.

2006/48/EC sayılı yönergeninin 150. maddesi, karşılıklı tanımaya tâbi faaliyetler listesinin genişletilmesi ya da listede kullanılan terminolojinin malî piyasalarda ortaya çıkan gelişmelere uyarlanması gerektiğinde, 151. maddede belirtilen esnek bir yolun izlenmesini öngörmüştür. Buna göre, listenin içeriğinde ve terminolojide değişiklikler yapma gereği doğduğunda, 2006/512/EC sayılı Konsey Kararı ${ }^{38}$ ile bazı hükümleri değiştirilmiş olan 1999/468/EC sayılı Konsey Kararı'nın ${ }^{39}$ 7(3) ve 8 numaralı maddeleri dikkate alınarak 5. maddesinde açıklanan usul uygulanacaktır.

2006/48/EC sayılı yönergeye ekli I numaralı listede sayılan işlemler, klâsik ticaret bankacılığına ilişkin olanların yanı sıra, yatırım bankalarınca yapılan bazı işlemleri de kapsamaktadır. Listenin karma niteliği, gerek ticaret bankalarına gerekse yatırım bankalarına özgü işlemleri yapabilen evrensel (universal) banka türünün Avrupa Birliği'ne üye olan Devletlerde giderek yaygınlaşması sonucunu doğurabilecektir. Gerçekten, 23. maddenin koyduğu koşulları yerine getirerek ülkesinde faaliyet izni almış olan kredi kurumları, şube açtıkları ya da hizmet sundukları öteki Üye Devletlerde, ulusal kredi kurumlarına yasaklanmış olsa da, Liste'de sayılan işlemleri yapma hakkına sahiptirler. Dolayısıyla, evrensel bankacılığın yaygın olduğu Almanya ve Hollanda gibi Üye Devletlerdeki kredi kurumları, yatırım bankacılığı ile ticaret bankacılığını birbirinden ayıran ve her ikisinin aynı banka tarafından yapılmasına izin vermeyen Üye Devletlerde şube açarak ya da sınır ötesi hizmet sunarak faaliyet gösterirken, ticaret bankacılığına özgü olanların yanı sıra yatırım bankacılığına ait işlemleri de yapabileceklerdir. $\mathrm{Bu}$ durumda Üye Devletlerin, merkezleri kendi ülkelerinde bulunan kredi kurumlarına eşit rekabet koşulları sağlayabilmek için, evrensel bankacılık sistemini kabul etmeleri kaçınılmaz olacaktır. Böylece, Avrupa Birliği kurumlarının doğrudan bir düzenlemesi olmasa da. serbest piyasa ekonomisinin, Üye Devletlerde kredi kurumlarına uygulanan kuralları birbirlerine yaklaştırması ve uyumlulaştırması gibi olumlu bir sonuç da ortaya çıkacaktır.

Evrensel bankacıllı̆̆ı Üye Devletlerde yaygınlaşmasından doğabilecek olumlu başka sonuçlar da vardır. Kredi kurumlarının geleneksel bankacılık işlemleri ile birlikte sermaye piyasası işlemlerini de yapabilmeleri, günümüzde hacmi giderek büyüyen menkul klymetleştirme (securitization) ve mevduat konusunda şiddetlenen rekabet yüzünden banka kârlarında

38 Council Decision of 17 July 2006 amending Decision 1999/468/EC laying down the procedures for the exercise of implementing powers conferred on the Commission (2006/512/EC), OJ L 200 22.07.2006, sh.11-13.

39 Council Decision of 28 June 1999 laying down the procedures for the exercise of implementing powers conferred on the Commission (1999/468/EC), OJ L 184 17.07.1999, sh.23-26. 
ortaya çıkması olası azalma eğilimini durdurabilir; hatta tersine çevirebilir. Ayrıca, kredi kurumlarının sermaye piyasalarına girmeleri, bu piyasalarda derinliğin ve likiditenin artmasına katkıda bulunabilir. A.B.D.' dekiler ya da Japonya'dakiler kadar güçlü sermaye piyasası kuruluşlarının bulunmadığı Avrupa Birliği ülkelerinde bu katkı özel bir öneme sahiptir. Evrensel bankacılık türünün yaygınlaşmasıyla Avrupa Birliği'nin globalleşen malî piyasalarda daha büyük bir rekabet gücü kazanacağı söylenebilir. ${ }^{40}$

Hiç kuşkusuz, Tek Bankacılık Lisansı'nın olanaklarından yalnız Üye Devletlerde kurulmuş olan kredi kurumları yararlanabilirler. Bir başka deyişle, merkezleri üçüncü bir ülkede bulunan kredi kurumlarının Üye Devletlerde açacakları şubeler, Tek Bankacılık Lisansı'nın sağladığı kolaylıklardan her hangi bir biçimde istifade edemezler. Roma Antlaşması'na göre Toplulukta yerleşme ve sınır ötesi hizmet sunma serbestileri olmayan bu kredi kurumlarının Üye Devletlerde açmak istedikleri şubeler, ilgili Devletin ulusal hukuk düzenlerine tâbidirler; açılmasına izin verilip verilmeyeceğini; verilecekse hangi koşullara uyarak faaliyet göstereceklerini ilgili Üye Devlet serbestçe kararlaştırabilir. Elbette, bu şubelerin Üye Devlette uymakla yükümlü tutulacakları koşullar, merkezleri öteki Üye Devletlerde bulunan kredi kurumlarının açacakları şubelerin yerine getirmeleri gereken koşullardan daha hafif olamayacaktır. Buna karşıllk, Üye Devletlerde üçüncü ülkelerden gelen sermaye ile kurulmuş olan kredi kurumları ya da üçüncü ülkelerdeki kredi kurumlarının Üye Devletlerdeki yavru kuruluşu olan kredi kurumları, Tek Bankacılık Lisansı'ndan yararlanabilirler. Gerçekten de, Üye Devletlerde Topluluk düzenlemelerine uygun biçimde kurulmuş ve faaliyet izni almış olan bu kurumların, sermayeleri kime ait olursa olsun, hukuksal açıdan ulusal sermayeli kredi kurumlarından farkları yoktur. Doğal olarak, bir Üye Devletteki kredi kurumunun başka bir Üye Devletteki yavru kuruluşu da, eğer faaliyet izni koşullara uygunsa, Tek Bankacılık Lisansı'nın olanaklarından yararlanabilir.

2006/48/EC sayılı yönergenin önsözünün 14. paragrafında, "köken Üye Devletlerinde faaliyet izni almış olan kredi kurumları, EK I'de listelenmiş olan faaliyetlerin birini ya da tümünü Topluluğun her yerinde şube açmak ya da hizmet sunmak suretiyle yapabilirler.” denmiş olmasına bakarak, Tek Bankacılık Lisansı almış olan kredi kurumlarının Karşılıklı Tanımaya Tâbi Faaliyetler Listesi'nin kapsamı dışında kalan ve kendi ülkelerinde eşdeğer biçimde düzenlenmemiş olan faaliyetlerinin, şube açılan ya da sınır ötesi hizmet sunulan Üye Devletteki ulusal düzenlemelere tâbi olacağı söylenebilir. Doğal olarak, bu faaliyetlerin yapılması sırasında kredi kurumunun kendi ülkesinde uyguladığı finansal teknikleri kullanması da söz konusu olamaz.

40 Bk.George S.ZAVVOS: Banking Integration and 1992: Legal Issues and Policy Implications, Harvard International Law Journal, vol:31 No:2, Spring 1990, sh.481. 
IX.Tek Bankacılık Lisansı ve Malî Kurumlar: Daha önce de vurgulandığı üzere, 2006/48/EC sayılı yönergenin 23. maddesi hükmünden, kural olarak, faaliyet izinlerinde EK I' de yer alan işlemleri yapabileceği belirtilmiş olan kredi kurumları yararlanabilir; kredi kurumu tanımına uygun nitelikler taşımayan kurumlar, Yönerge'nin ekindeki işlemlerin birini ya da tümünü yapsalar da 23. maddenin verdiği hakları kullanamazlar. Bununla birlikte Yönerge, Üye Devletlerin bazılarında kredi kurumlarının EK I'deki işlemlerin bir bölümünü doğrudan yapmalarının yasaklanmış olmasını dikkate alarak bir istisna hükmü getirmiştir. 24. maddede yer alan bu istisna hükmü, ülkelerinde kendilerine yasaklanmış işlemleri yapmak üzere yavru firmalar kuran ve böylece söz konusu faaliyetleri dolaylı olarak yapma yoluna giden kredi kurumlarının 23. maddeyle sağlanan kolaylıklardan yararlanmalarına olanak sağlamaktadır. Bu suretle, örneğin bankalara finansal kiralama hizmetleri yapma izninin verilmediği Üye Devletlerde kredi kurumlarınca kurulan leasing firmalarına 23. maddenin sağladığı olanaklardan yararlanma yolu açılmış; ana kurumun başka Üye Devletlerdeki kredi kurumları ile eşit koşullarda rekabet edebilme gücü, dolaylı da olsa, korunmuş olmaktadır.

24. maddenin birinci bendine göre, Üye Devletlerde bir kredi kurumunun yavru kuruluşu veya iki ya da daha çok sayıda kredi kurumunun ortak yavru kuruluşu olan malî kurumlar, ana sözleşmelerinde izin verilmiş olma koşuluyla, Ek I'deki işlemleri, tüm Üye Devletlerde şube açarak ya da hizmet sunarak yapabilirler. 2006/48/EC say1lı yönergenin 4. maddesinin 5. bendine göre "malî kurum, kredi kurumu olmayan fakat ana faaliyeti hisse senetleri iktisap etmek ya da EK I'deki listenin 2 ilâ 12. sirasında kayıtlı faaliyetlerden birini ya da daha fazlasını yapmak olan bir teşebbüsü ifade eder."

Bir malî kurumun 24. madde hükmünden yararlanabilmesi için, ana sözleşmesinde yer alması gereken iznin yanı sıra,

1. ana teşebbüs ya da teşebbüslerin, malî kurumun ilgili Üye Devlette tâbi olduğu hukuka göre, kredi kurumu olarak faaliyet izni almış olmaları;

2. EK I'de sayılan faaliyetlerin aynı Üye Devletin ülkesinde fiilen yapılmakta olmasi;

3. ana teşebbüs ya da teşebbüslerin, malî kurumda sahip oldukları sermaye paylarından kaynaklanan oy haklarının \%90'ını ya da daha fazlasını ellerinde bulundurmalar1;

4. ana teşebbüs ya da teşebbüslerin, malî kurumun basiretle yönetildiği hususunda yetkili mercilere tatmin edici bilgi vermeleri ve merkezin bulunduğu Üye Devletteki yetkili mercilerin oluru ile, malî kurumun üstlenmiş olduğu taahhütleri müştereken ve müteselsilen garanti ettiklerini beyan etmiş olmaları; 
5. malî kurumun, özellikle EK I'deki faaliyetler bağlamında, asgarî özkaynak gereğinin belirlenmesi, büyük risklerin izlenmesi ve iştiraklerinin sınırlanması açılarından ana teşebbüsün ya da her bir ana teşebbüsün konsolide gözetim ve denetimi kapsamına alınması;

zorunludur.

Malî kurumun 24. maddede sıralanmış olan bu koşullara ne ölçüde uyduğunu irdeleme görevi, merkezinin bulunduğu Üye Devletteki (köken Devlet) yetkili mercilere aittir. Yetkili merciler, yaptıkları incelemeden olumlu sonuçlar alırlarsa malî kuruma bir Uygunluk Belgesi (certificate of compliance) verirler. Bir başka Üye Devlette şube açmak ya da sınır ötesi hizmet sunmak isteyen malî kurum, kendi ülkesindeki yetkili mercilere sunmakla yükümlü olduğu ve bu projesini açıklayan bildirime söz konusu belgeyi de eklemek zorundadır. Köken Devletin yetkili mercileri, bu belgeyi ve gereken öteki bilgileri şube açılacak ya da sınır ötesi hizmet sunulacak Üye Devletin yetkili mercilerine iletirler. Köken Devletteki yetkili merciler, kredi kurumları gibi, malî kurumların da gerek ülkedeki gerekse öteki Üye Devletlerdeki faaliyetlerinin gözetim ve denetiminden sorumludurlar.

Uygunluk belgesinde yer alan ve yukarda açıklanan koşullardan her hangi birinin varlığı sona erdiğinde, malî kurumun merkezinin bulunduğu Üye Devletteki yetkili merciler, şube açılan ya da hizmet sunulan Üye Devletin yetkili mercilerine durumu bildirmekle yükümlüdürler. Malî kurumun bildirimden sonraki faaliyetleri, şube açılan ya da hizmet sunulan Üye Devletin yasalarına ve hukuksal düzenlemelerine tâbi olur; bir başka deyişle, malî kurumun 24. maddenin sağladığı olanaklardan yararlanması sona erer.

X. Faaliyet İninin Geri Alınması: Kredi kurumlarına ülkelerindeki yetkili mercilerden verilen faaliyet izninin geri alınmasına yol açan genel nedenler, 2006/48/EC sayılı yönergenin 17. maddesinde siralanmıştır. Ayrıca, başka bazı yönergelerde de faaliyet izninin geri alınmasını gerektiren özel nedenlere yer verilmiştir.

2006/48/EC sayılı yönergenin 17. maddesine göre kredi kurumu,

1. ilgili Üye Devletin aksine bir düzenlemesi olmadığı durumlarda, verildiği tarihi izleyen 12 ay içinde faaliyet iznini kullanmamışsa; faaliyet iznini kullanmayacağını açıkca bildirmişse ya da faaliyetine altı ayı aşan bir süre ara vermişse;

2. faaliyet iznini yalan beyanda bulunarak ya da başka usulsüz yollarla elde etmişse;

3. faaliyet izninin verildiği sıradaki koşullara artık sahip değilse;

4. yeterli ölçüde özkaynağa artık sahip değilse ya da alacaklılarına olan yükümlülüklerini yerine getirebileceğine artı güvenilmiyorsa ve özellikle de kendisine tevdi edilmiş olan varlıklar için artık güvence sağlayamıyorsa; 
5. faaliyet izninin geri alınması için ulusal düzenlemelerin öngördüğü nedenlerden biri ortaya çıkmışsa;

faaliyet iznini vermiş olan yetkili merciler bu izni geri alabilirler.

“Avrupa Parlâmentosu'nun ve Konseyi'nin Mevduat Garanti Sistemlerine İlişkin 94/19/EC sayılı ve 30 Mayıs 1994 günlü Yönergesi"nin ${ }^{41}$ 3. maddesinin 5. maddesine göre de yetkili merciler, maddenin 3. ve 4. bendlerinde öngörülen önlemlerin uygulanmasına karşın, bağlı bulunduğu mevduat-garanti sistemine karşı yükümlülüklerini yerine getirmeyen kredi kurumuna vermiş oldukları faaliyet iznini geri alacaklardır.

Faaliyet izninin geri alınmasına ilişkin bir başka hüküm, "Avrupa Parlâmentosu'nun ve Konseyi'nin Kredi Kurumlarının Yeniden Yapılandırılmasına ve Tasfiyesine İlişkin 2001/24/EC sayılı ve 4 Nisan 2001 günlü Yönergesi”nin ${ }^{42} 12$. maddesinde yer almaktadır. Bu maddeye göre, bir kredi kurumuna ilişkin olarak düzeltici, iyileştirici, kısıtlayıcı önlemler, başka bir deyişle, yeniden yapılandırma önlemleri alma yoluna gidilmeksizin ya da bu önlemlerin başarısız olmasının ardından tasfiye sürecinin başlatılmasına karar verilirse faaliyet izni geri alınacaktır.

Yetkili mercilerce faaliyet izninin geri alınmasına ilişkin olarak verilen kararların gerekçeli olması ve ilgililere, ayrıca Komisyon'a bildirilmesi zorunludur. 2006/48/EC sayılı yönergenin 35. maddesine göre bir kredi kurumunun faaliyet izni geri alındığında, merkezinin bulunduğu Üye Devletteki yetkili merciler, kurumun şube açtığı ya da sınır ötesi hizmet sunduğu tüm Üye Devletlerin yetkili mercilerine bilgi vermekle yükümlüdürler. Kendilerine bilgi verilen yetkili merciler, faaliyet izni geri alınan kredi kurumunun bu tarihten sonra ülkelerinde işlem yapmasını önleyecek ve mevduat sahiplerinin çıkarlarını koruyacak önlemleri almak zorundadırlar.

XI. Hukuk Yollarına Başvurma Hakkı: 2006/48/EC sayılı yönergenin 55. maddesi, kredi kurumlarının kendilerine ilişkin olarak alınan kararlara karşı hukuk yollarına başvurma hakkını düzenlemektedir. Söz konusu maddeye göre Üye Devletler, 2006/48/EC sayılı yönerge uyarınca Avrupa Birliği'nde kabul edilmiş kanunlara, tüzüklere ve idarî düzenlemelere uygun olarak alınan kararlara karşı kredi kurumlarının yargıya başvurma yolunu açık tutmakla yükümlüdürler. Kredi kurumları, faaliyet izni almak için yaptıkları ve yürürlükteki hükümlere göre gerekli tüm bilgileri içeren başvuruya ilişkin olarak altı ay içinde bir karar verilmemesi durumunda da yarg1 yoluna gitme hakkına sahiptirler.

${ }^{41}$ Directive 94/19/EC of the European Parliament and of the Council of 30 May 1994 on the deposit-guarantee schemes, OJ L 135 31.05.1994, sh.5-14.

${ }^{42}$ Directive 2001/24/EC of the European Parliament and of the Council of 4 April 2001 on the reorganisation and winding up of credit institutions, OJ L 125 05.05.2001, sh.15-23. 
XII. Kredi Kurumlarının Faaliyetlerinin Sona Ermesi: Bir teşebbüsün mevduat ya da geri ödenmek kaydıyla fonlar kabul etmek ve kendi hesabına borç vermek üzere kurulması ile yetkili mercilerden faaliyet izni almasının birbirinden ayrı aşamalar olduğuna bakarak faaliyet izninin geri alınmasının, kredi kurumunun kamudan mevduat ya da geri ödenmek üzere fonlar toplama ve kendi hesabına kredi verme işlemleri yapmasını engellese de hukukî varlığını hemen sona erdirmeyeceği ileri sürülebilir. Ne var ki, amacını gerçekleştirme olanağı kalmayan, büyük bir olasılıkla borç ödeme gücünü yitirmiş bir teşebbüsün hukukî varlığını sürdürmesi olanaksızdır. Nitekim, 2001/24/EC say1lı yönergenin önsözünün 15. bendinde, yeniden yapılandırma yoluna gidilmediği ya da bu amaçla uygulanan önlemler sonuçsuz kaldığı takdirde, güçlüklerle karşılaşan kredi kurumunun tasfiye edilmesi gerektiği ifade edilmiştir. Tasfiye sürecinin başlatılması konusunda karar verme yetkisi, kredi kurumunun merkezinin bulunduğu Üye Devletteki tasfiyeden sorumlu idarî ya da kazaî mercilere aittir. Aksi Yönerge'de belirtilmemişse kredi kurumunun tasfiyesi, merkezinin bulunduğu Üye Devletteki yasalara, tüzüklere ve usullere göre yürütülür.

Kredi kurumlarının iradî tasfiye yoluna başvurmaları, kurumların faaliyetini sona erdiren bir başka nedendir. 2001/24/EC sayılı yönergenin 11. maddesine göre, kredi kurumunun yönetim organları iradî tasfiye kararı almadan önce, merkezlerinin bulunduğu Üye Devletteki yetkili mercilerin görüşünü almak zorundadırlar. Aynı maddenin 2. bendine göre de, iradî tasfiye kararının alınmış olması Üye Devletteki idarî ya da kazaî mercilerin kredi kurumuna ilişkin olarak düzeltici, iyileştirici ya da kısıtlayıcı, başka bir deyişle yeniden yapılandırıcı önlemlerin uygulanmasını veya tasfiye sürecinin başlatılmasını doğrudan kararlaştırmalarına engel olmaz.

XIII. Sonsöz: Kredi kurumlarına ilişkin olarak çıkarılmış kapsamlı sayılabilecek ilk düzenleme olan Birinci Bankacılık Yönergesi'nin önsözü incelendiğinde, Topluluğun tümünde bankacılık işlemlerinin serbest rekabet koşullarında yapılabileceği tek bir piyasanın ya da kredi kurumları tekpazarının oluşturulmasını, Avrupa Topluluğu'nun daha başlangıçta bir hedef olarak belirlediği görülebilmektedir. Ne var ki bankacılık, geleneksel olarak, her ülkede yasalarla ve idarî düzenlemelerle sıkı biçimde kayıtlanmış ekonomik kesimlerin başında yer tutar ve söz konusu kayıtlamaların kapsamı ile içeriği ülkeden ülkeye önemli ölçüde değişiklik gösterir. Hiç kuşkusuz, Üye Devletlerde kredi kurumlarına uygulanan kurallar arasındaki büyük farklar giderilmediği sürece, salt Roma Antlaşması'nda öngörülen yerleşme ve sınır ötesi hizmet sunma serbestilerinin sağlanması, rekabetçi bir bankacılık piyasasını oluşturmaya yetmeyeceği gibi, tasarrufların ve kredi kurumlarından alacaklı olanların korunması, ülkelerin malî sistemlerinde güveni ve istikrarı bozacak sistemik krizlerin önlenmesi gibi sonuçları da tek başına doğuramayacaktı. Bu nedenle, Birinci Bankacılık Yönergesi'nin önsözünde belirtildiği gibi, Üye Devletlerde kredi kurumlarına uygulanan 
kurallar arasında hedefe ulaşmayı en fazla engelleyici olan farkların azaltılması gerekiyordu. Bununla birlikte, söz konusu farkların azaltılması, dolayısıyla da kredi kurumları tekpazarının oluşturulması geniş kapsamlı tek bir yönerge ile ve bir hamlede gerçekleştirilemeyeceğinden ard arda bir dizi yönerge çıkarılarak hedefe aşamalı olarak ulaşılması yoluna gidildi; Üye Devletlerde kredi kurumlarının kuruluşuna, faaliyete geçmelerine, faaliyete son vermelerine ve tasfiyelerine, tâbi olacakları basiret kuralları ile gözetim ve denetim sistemlerine ilișkin ulusal düzenlemelerin temel hükümleri birbirleriyle uyumlulaştırılmaya çalışıldı. Avrupa Birliği'nde son otuz yıldır devam eden kredi kurumları tekpazarını oluşturma sürecinin temel taşları, yerleşme ve sınır ötesi hizmet sunma serbestileri ile birlikte Üye Devletlerdeki ulusal düzenleyici kuralların asgarî ölçüde de olsa birbirleriyle uyumlulaştırılması, karşılıklı tanıma ilkesi ve köken Devletin gözetim ve denetim sorumluluğunu üstlenmesidir. 